\title{
Identification of Reference Genes in Human Myelomonocytic Cells for Gene Expression Studies in Altered Gravity
}

\author{
Cora S. Thiel, ${ }^{1,2,3}$ Swantje Hauschild, ${ }^{1,2,3}$ Svantje Tauber, ${ }^{1,2,3}$ Katrin Paulsen, \\ Christiane Raig, ${ }^{1}$ Arnold Raem, ${ }^{4}$ Josefine Biskup, ${ }^{1,2}$ Annett Gutewort, ${ }^{1,2}$ Eva Hürlimann, \\ Felix Unverdorben, ${ }^{1}$ Isabell Buttron, ${ }^{1}$ Beatrice Lauber, ${ }^{1}$ Claudia Philpot, ${ }^{5}$ Hartwin Lier, ${ }^{6}$ \\ Frank Engelmann, ${ }^{6,7}$ Liliana E. Layer, ${ }^{1}$ and Oliver Ullrich ${ }^{1,2,3,8}$ \\ ${ }^{1}$ Institute of Anatomy, Faculty of Medicine, University of Zurich, Winterthurerstraße 190, 8057 Zurich, Switzerland \\ ${ }^{2}$ Department of Machine Design, Engineering Design and Product Development, Institute of Mechanical Engineering, \\ Otto-von-Guericke-University Magdeburg, Universitätsplatz 2, 39106 Magdeburg, Germany \\ ${ }^{3}$ Study Group "Magdeburger Arbeitsgemeinschaft für Forschung unter Raumfahrt- und Schwerelosigkeitsbedingungen" (MARS), \\ Otto-von-Guericke-University Magdeburg, Universitätsplatz 2, 39106 Magdeburg, Germany \\ ${ }^{4}$ Arrows Biomedical Deutschland GmbH, Center for Nanotechnology at the Westfälische Wilhelms-Universität Münster, \\ Heisenbergstraße 11, 48149 Münster, Germany \\ ${ }^{5}$ German Aerospace Center, Space Agency, Königswinterer Straße 522-524, 53227 Bonn, Germany \\ ${ }^{6} \mathrm{KEK}$ GmbH, Kemberger Straße 5, 06905 Bad Schmiedeberg, Germany \\ ${ }^{7}$ University of Applied Science Jena, Carl-Zeiss-Promenade 2, 07745 Jena, Germany \\ ${ }^{8}$ Zurich Center for Integrative Human Physiology (ZIHP), University of Zurich, Winterthurerstraße 190, 8057 Zurich, Switzerland
}

Correspondence should be addressed to Oliver Ullrich; oliver.ullrich@uzh.ch

Received 14 May 2014; Accepted 4 September 2014

Academic Editor: Jack J. W. A. Van Loon

Copyright (C) 2015 Cora S. Thiel et al. This is an open access article distributed under the Creative Commons Attribution License, which permits unrestricted use, distribution, and reproduction in any medium, provided the original work is properly cited.

Gene expression studies are indispensable for investigation and elucidation of molecular mechanisms. For the process of normalization, reference genes ("housekeeping genes") are essential to verify gene expression analysis. Thus, it is assumed that these reference genes demonstrate similar expression levels over all experimental conditions. However, common recommendations about reference genes were established during $1 \mathrm{~g}$ conditions and therefore their applicability in studies with altered gravity has not been demonstrated yet. The microarray technology is frequently used to generate expression profiles under defined conditions and to determine the relative difference in expression levels between two or more different states. In our study, we searched for potential reference genes with stable expression during different gravitational conditions (microgravity, normogravity, and hypergravity) which are additionally not altered in different hardware systems. We were able to identify eight genes (ALB, B4GALT6, GAPDH, HMBS, YWHAZ, ABCA5, ABCA9, and ABCC1) which demonstrated no altered gene expression levels in all tested conditions and therefore represent good candidates for the standardization of gene expression studies in altered gravity.

\section{Introduction}

Since several limiting factors for human health and performance in microgravity have been clearly identified [1], it has been concluded that substantial research and development activities are required in order to provide the basic information for appropriate integrated risk management, including efficient countermeasures and tailored life support systems [2]. In particular, bone loss during long stays in weightlessness still remains an unacceptable risk for longterm and interplanetary flights [3], and serious concerns arose whether spaceflight-associated immune system weakening ultimately precludes the expansion of human presence beyond Earth's orbit [4]. The immune and skeletal systems are tightly linked by cytokine and chemokine networks and direct cell-cell interactions $[5,6]$, and the immune system influences metabolic, structural, and functional changes in bones directly [6]. Both systems share common cellular 
players such as the osteoclasts, which are bone-resident macrophages and derivatives of monocytic cells. Therefore, knowing the cellular and molecular mechanisms of how gravity influences cell function is a valuable requirement to provide therapeutic or preventive targets for keeping important physiological systems fully functional during longterm space missions.

Since the first pioneering in vitro studies that revealed that cells of the immune system are sensitive to changes of gravitational force [7-10], several studies in real and simulated microgravity have confirmed microgravity-induced alterations in the molecular mechanisms and signal transduction processes in leukocytes, including the monocyte/macrophage system (MMS) [11, 12]. The MMS belongs to the innate immune system and is characterized by a fast but nonspecific immune reaction, the first line of defense against invading pathogens. Cells of the MMS in microgravity demonstrated disturbed cytokine release [13-15], reduced oxidative burst $[16,17]$, alteration of the cytoskeleton [18], and reduction in their locomotion ability [19]. Importantly, analysis of gene expression of monocytes during an ISS experiment revealed significant changes in gene expression associated with macrophageal differentiation [20].

Differential gene expression analyses are a widely used method to investigate the influence of different treatments or conditions on a cell system. The resulting changes on the molecular level can be investigated either by reverse transcription quantitative real-time PCR (RT-qPCR) as major technique for the sensitive and robust analysis of expression levels of specific genes [21-27] and microarrays for whole genome or transcriptome analyses [28].

After the genome sequencing era, when numerous genomes were completely decoded, the focus of interest shifted towards genome wide expression level analyses, so that a snapshot of the whole genome expression profile is obtained in a single experiment [28-30], offering also a possibility to obtain an insight into networks and pathways of biomolecular interactions on a large scale [29-33]. The technology behind microarray analysis developed fast, and different suppliers used different protocols for, for example, hybridization and data normalization. Therefore, it was and still is difficult to establish standards for the experimental procedure and processing of the raw data obtained [30]. Consequently, a concept for the development of standards for microarray experiments and data has been presented by the microarray gene expression database group (MGED) describing the minimum information about a microarray experiment (MIAME, [34]). This compilation covers (1) the experimental design, (2) the array design, (3) samples, (4) hybridizations, (5) measurements, and (6) normalization controls [34]. Also for RT-qPCR technique [35-38], standard guidelines $(\mathrm{MIQE}=$ minimum information for the publication of quantitative real-time PCR) were developed [27, 39-41].

One of the most crucial requirements of standardization are suitable internal controls so called reference genes that are used for data normalization, which are important to account for differences in the amount and quality of starting material as well as reaction efficiency [42]. GAPDH, HPRT, $\beta$-actin, tubulin, and ribosomal RNA genes are typical examples for frequently used reference genes [43-45]. However, reference genes have to be tested for their suitability as an endogenous control in each case prior to the experiment. This is of high importance substantiated by many studies reporting expression effects of classical "housekeeping genes" upon experimental treatments [46-49]. A selection of several reference genes used simultaneously can also be a good way to further increase reliability of the resulting data $[50,51]$. In fact, recommendations state to identify three stable reference genes for each planned assay to assure a reliable outcome $[50,52]$. The identification of stably expressed reference genes can be performed in a pilot study using dedicated algorithms like geNorm or BestKeeper or a combination hereof, where a minimum of eight potential reference genes are tested and ranked according to their stability being an indication for their suitability as control genes for normalization $[50,51]$. Candidate reference genes for such a study may be, for example, chosen from the literature or from experimental data obtained from microarray analysis $[27,51]$.

However, common recommendations about reference genes were established during $1 \mathrm{~g}$ conditions and therefore their applicability in studies with altered gravity conditions has not been intensively demonstrated so far. Although, there are numerous publications describing differential gene expression analyses under simulated and real microgravity conditions in various cells types and tissues (supplementary Table 1 available online at http://dx.doi.org/10.1155/ 2014/363575), a systematic research on reference genes stable under altered gravity conditions has not been published yet.

In our study, we used microarray analyses to investigate the differential gene expression in U937 cells, a myelomonocytic human cell line, exposed to short-term (20 seconds) and middle-term (6 to 7 minutes) microgravity and hypergravity during parabolic flights and sounding rocket flights, two platforms commonly used by researchers to investigate the effects of real microgravity. Our experimental goal was to identify potential reference genes that can be recommended to the community of gravitational biology for differential expression analysis performed with cells of the immune system on those two frequently used platforms. Therefore, we chose 22 reference genes widely used throughout the literature and screened our microarray data for these particular genes evaluating their stability for possible application as control genes. Besides the highly conserved ribosomal RNA genes and others, ABC transporter and tRNA genes belong to evolutionary well-conserved genes as well. Since ribosomal RNA and tRNA genes are not represented on the array, we decided to adhere to tRNA related genes like tRNA synthetases, as these play a central role in basal cellular functions and should be robustly expressed to ensure cell survival. Therefore, our study comprised published reference genes, $\mathrm{ABC}$ transporters, and tRNA related genes.

\section{Material and Methods}

2.1. Cell Culture. U937 cells (ATCC CRL1593.2) originating from a diffuse histiocytic lymphoma, displaying many monocytic characteristics, were used as a model cell line to investigate the differential gene expression under altered gravity 
conditions in monocytic/macrophageal cells. U937 cells were cultured in RPMI 1640 medium (Biochrom/Merck Millipore, Germany), supplemented with 10\% fetal bovine serum (FBS Superior; Biochrom/Merck Millipore, Germany), 2 mM glutamine (Gibco/Life Technologies, Germany), and $100 \mathrm{U} / \mathrm{mL}$ penicillin as well as $100 \mu \mathrm{g} / \mathrm{mL}$ streptomycin (Gibco/Life Technologies, Germany). Cells were seeded with a density of $0.2 \times 10^{6}$ cells $/ \mathrm{mL}$ and the medium was exchanged every 48 hours. Cells were harvested by centrifugation at $300 \mathrm{~g}$ for $5 \mathrm{~min}$ at room temperature, resuspended in fresh medium, and an aliquot was used for an adequate dilution with trypan blue to count the vital cell number. Cells were reseeded in fresh medium at a concentration of $0.2 \times 10^{6}$ cells $/ \mathrm{mL}$.

2.2. Parabolic Flight Experiments. We designed and constructed an experiment module suitable to perform cell culture experiments with living mammalian cells during parabolic flights on board the Airbus A300 ZERO-G. During the 19th DLR parabolic flight campaign (PFC), we focused on the analysis of differential gene expression in U937 cells considering the different gravity conditions: in-flight $1 \mathrm{~g}, 1.8 \mathrm{~g}$, and $0 \mathrm{~g}$. Experiments were only performed during the first parabola to assure that the investigated differential gene expressions are generated by a direct effect of gravitational change and not an accumulated long-term effect. During the 19th DLR PFC, experiments were reproduced on two independent flight days.

In search of rapidly responsive molecular alterations in mammalian cells, short-term microgravity provided by parabolic flight maneuvers is an ideal instrument to elucidate initial and primary effects, without the influence and interference of secondary signal cascades. Parabolic flights provide $1 \mathrm{~g}, 1.8 \mathrm{~g}$, and microgravity $(\mu \mathrm{g})$ with a quality of approximately $10^{-2}$ to $10^{-3} \mathrm{~g}$. For the 19th DLR PFC, $1 \times 10^{7}$ U937 cells in $10 \mathrm{~mL}$ medium (RPMI 1640 supplemented with $100 \mathrm{U} / \mathrm{mL}$ penicillin, $100 \mu \mathrm{g} / \mathrm{mL}$ streptomycin, $250 \mathrm{ng} / \mathrm{mL}$ amphotericin B (Gibco/Life Technologies, Germany), 2 mM glutamine, and $2 \%$ FBS (i.e., serum starved)) were filled into $200 \mathrm{~mL}$ Nutrimix bags (B. Braun Melsungen, Germany) and transported from the home laboratory to the preflight preparation laboratories at the NOVESPACE premises in Bordeaux, France. After arrival, cells were destarved by addition of $0.8 \mathrm{~mL}$ FBS per Nutrimix bag and used for the flight experiment on the following day. For the flight day, the Nutrimix bags were placed in a solid plastic container to create a double containment to prevent spillage of fluids in the aircraft in case of leakage which is strictly prohibited by the NOVESPACE regulations. The rapid preservation of the effects of altered gravity on the gene expression in the U937 cells was achieved by injection of $50 \mathrm{~mL}$ of RLT buffer (Qiagen, Germany), a lysis buffer immediately lysing cells and tissues prior to RNA isolation. The $1 \mathrm{~g}$ in-flight controls were performed $5 \mathrm{~min}$ before the first parabola and the $1.8 \mathrm{~g}$ sample directly before the microgravity phase of the first parabola. The $\mu \mathrm{g}$ samples were fixed directly at the end of the microgravity phase of the first parabola. Samples were transported to the laboratory immediately after landing. $1 \mathrm{~g}$ ground controls were performed immediately after landing using the experimental module in the aircraft. In total, 30 samples were obtained during two parabolic flight days: $6 \times 1 \mathrm{~g}$ ground controls, 9x $1 \mathrm{~g}$ in-flight controls, $6 \times 1.8 \mathrm{~g}$ and 9x $\mu \mathrm{g}$.

2.3. RNA Isolation after the Parabolic Flight Experiments. After landing of the aircraft and transport of the samples to the laboratory on site facilities, the containers were disassembled, the Nutrimix bags were gently agitated, and the lysed cell solution was filled into a T75 straight neck cell culture flask. The cell solution was vortexed for $10 \mathrm{sec}$ and passed four times through a $\varnothing 0.8 \times 120 \mathrm{~mm}$ needle (B. Braun Melsungen, Germany) fitted to a $50 \mathrm{~mL}$ syringe. $50 \mathrm{~mL}$ of absolute ethanol was added and precipitates were resuspended by vigorous shaking. A valve and a sterile connective piece were placed on a QIAvac 24 plus vacuum system (Qiagen, Germany) and an RNA maxi column (Qiagen, Germany) was attached to the connective piece. A vacuum of $-200 \mathrm{mbar}$ was adjusted, and the column was loaded with the lysed cell suspension. Then, the valve was closed, and the column was centrifuged at $4000 \mathrm{~g}$ for $3 \mathrm{~min} .15 \mathrm{~mL}$ of buffer RW1 (Qiagen, Germany) was applied for washing membrane bound RNA. After centrifugation at $4000 \mathrm{~g}$ for $7 \mathrm{~min}$, the flow through was discarded and two washing steps with $10 \mathrm{~mL}$ RPE buffer (Qiagen, Germany) followed with centrifugation at $4000 \mathrm{~g}$ for $3 \mathrm{~min}$ and $10 \mathrm{~min}$, respectively. The column bound RNA was eluted by application of $600 \mu \mathrm{L}$ of RNase-free water (Qiagen, Germany), incubation for $1 \mathrm{~min}$ at room temperature, and centrifugation for $4 \mathrm{~min}$ at $4000 \mathrm{~g}$. The elution step was repeated with the first eluate. The RNA was transported at approximately $-150^{\circ} \mathrm{C}$ in a Cryo Express dry shipper (CX100, Taylor-Wharton, USA) prepared with liquid nitrogen and stored at $-80^{\circ} \mathrm{C}$ until the processing of the RNA for the microarray analysis.

2.4. Experiments during the TEXUS-49 Sounding Rocket Campaign. For the TEXUS-49 campaign at ESRANGE (European Space and Sounding Rocket Range, Kiruna, Sweden), U937 cells were cultured in the fully installed laboratories on site. Cells were seeded with a density of $0.2 \times 10^{6}$ cells $/ \mathrm{mL}$ and the medium was exchanged every 48 hours as described above. On the launch day, cells were visually inspected, harvested, counted, and pooled to a concentration of $5 \times 10^{7}$ cells $/ \mathrm{mL}$. $0.5 \mathrm{~mL}$ of this cell suspension was filled in a sterile $3 \mathrm{~mL}$ plastic syringe shortly before the launch. Additionally, one syringe was filled with $0.3 \mathrm{~mL}$ of cell culture medium and another one with $1 \mathrm{~mL}$ Trizol LS (Life Technologies, Germany). The three syringes were mounted on a plastic block with a tubing system connecting them. This unit was finally integrated into the automatically operated experiment system. In total, 35 of these experiment units were prepared and were kept at $37^{\circ} \mathrm{C}$ until the integration into the payload of the rocket.

During the experimental run, firstly the $0.3 \mathrm{~mL}$ of medium, as a potential placeholder for an activation solution, and secondly the $1 \mathrm{~mL}$ of Trizol LS were injected to the cell suspension at defined time points to lyse the cells and preserve the current status of differential gene expression. This sequential injection of fluids was performed at $75 \mathrm{sec}$ after launch to monitor the so-called baseline (BL) directly 
before the $\mu \mathrm{g}$ phase and at $375 \mathrm{sec}$ after launch shortly before the end of the $\mu \mathrm{g}$ phase. A group of $1 \mathrm{~g}$ ground controls were kept on ground in the incubator simultaneously to the $\mu \mathrm{g}$ sample group.

TEXUS-49 consisted of a VSB-30 engine (S-30 solid rocket stage with an S-31 second stage) and of the payload. The rocket was launched on March 29, 2011 at 06:01 a.m. from the ESRANGE Space Center near Kiruna, Sweden. During the ballistic suborbital flight, an altitude of $268 \mathrm{~km}$ and $378 \mathrm{sec}$ of microgravity with a quality of $10^{-5} \mathrm{~g}$ were achieved. Further parameters include first stage peak thrust acceleration $6.3 \mathrm{~g}$, mean thrust acceleration $5.03 \mathrm{~g}$, burnout at $12.3 \mathrm{sec}$, and engine separation at $13.6 \mathrm{sec}$; second stage peak thrust acceleration $13.5 \mathrm{~g}$, mean thrust acceleration $7.30 \mathrm{~g}$, burnout at $43.0 \mathrm{sec}$, yo-yo despin at $56.0 \mathrm{sec}$, and engine separation at $59.0 \mathrm{sec}$.

2.5. RNA Isolation after the TEXUS-49 Sounding Rocket Campaign. Directly after landing, localization, and recovery of the payload, the experiment modules were dismantled and handed over to the scientists. The cell suspension was sheared three times with a $20 \mathrm{G}$ needle (B. Braun Melsungen, Germany) and distributed in two $2.0 \mathrm{~mL}$ tubes. $0.1 \mathrm{~mL}$ of chloroform (Sigma-Aldrich, Germany) was added, and the homogenate was vortexed for $15 \mathrm{sec}$ and incubated for $5 \mathrm{~min}$ at room temperature before a $15 \mathrm{~min}$ centrifugation step at $11000 \mathrm{~g}$ and $4^{\circ} \mathrm{C}$. The upper phase of both $2.0 \mathrm{~mL}$ tubes was transferred into a $15 \mathrm{~mL}$ tube, and $4 \mathrm{~mL}$ of RLT buffer as well as $3 \mathrm{~mL}$ of absolute ethanol was added and mixed. $4 \mathrm{~mL}$ of this solution was pipetted on an RNA Midi column (Qiagen, Germany) and centrifuged for $30 \mathrm{sec}$ at $3000 \mathrm{~g}$ and room temperature. The flow through was discarded and the residual $4 \mathrm{~mL}$ of RNA solution was loaded on the column and centrifuged for $5 \mathrm{~min}$ at $3000 \mathrm{~g}$ at room temperature. Then, the columns were washed twice with $2.5 \mathrm{~mL}$ of RPE buffer and centrifuged for $2 \mathrm{~min}$ and $5 \mathrm{~min}$, respectively, at $3000 \mathrm{~g}$ at room temperature. The RNA was eluted by addition of $250 \mu \mathrm{L}$ RNase-free water (Qiagen, Germany) to the column, incubation for $1 \mathrm{~min}$ at room temperature, and centrifugation for $3 \mathrm{~min}$ at $3000 \mathrm{~g}$ and room temperature. The eluate was loaded again onto the column, followed by a $1 \mathrm{~min}$ incubation and centrifugation for $5 \mathrm{~min}$ at $3000 \mathrm{~g}$ and room temperature. The isolated RNA was transferred into sterile cryotubes and stored until the return transport at approximately $-150^{\circ} \mathrm{C}$ in a Cryo Express dry shipper (CX-100, Taylor-Wharton, USA) prepared with liquid nitrogen. After arrival in the home laboratory, samples were stored at $-80^{\circ} \mathrm{C}$ until the processing of the RNA for the microarray analysis.

2.6. RNA Processing and Microarray Analysis. RNA quantity and purity were analyzed spectrophotometrically using a NanoDrop 1000 (Thermo Scientific, USA). Isolated RNA samples were all of high quality with $260 / 280 \mathrm{~nm}$ ratios between 1.9 and 2.1. The RNA integrity was measured using an Agilent 2100 Bioanalyzer (Agilent Technologies, USA). Only RNA with an RNA integrity number (RIN) > 8.7 was used for the following microarray analysis. $400 \mathrm{ng}$ total RNA was applied to Cy3-labeling with the "Low RNA Input Linear Amplification Kit, PLUS, One-Color” (Agilent Technologies) and hybridized for $17.5 \mathrm{~h}$ to a NimbleGen expression microarray $(12 \times 135,000$ features $)$ employing the "Gene Expression Hybridization Kit” (Agilent Technologies). Afterwards, arrays were washed and scanned by the Microarray Scanner G2505B (Agilent Technologies).

The image files of the scanner were analyzed with the NimbleScan Software 2.6 using the robust multiarray analysis (RMA) with the default parameters. RMA, a probe-level summarization method, identifies probes that are outliers in the overall behavior of the expression measured for a given gene. The contribution of outlier probes is reduced in the reported gene expression level, which has been demonstrated to improve the sensitivity and reproducibility of microarray results. In addition to screening outlier probes, NimbleScan software's implementation of RMA [53] used quantile normalization and background correction.

The normalized microarray data were analyzed using Partek Genomics Suite 6.6. Statistical analysis was performed using the one-way ANOVA and the false discovery rate (FDR) [54] for multiple-testing correction. Further, the coefficient of variation (CV) expressed in percent was calculated, also known as "relative variability." It equals the standard deviation divided by the mean. An integration tool (available at http://www.leonxie.com/referencegene.php) [50, 51, 55] of four algorithms (geNorm, NormFinder, BestKeeper, and the comparative delta-CT method) was used to evaluate the expression stability of the reference genes. On the basis of the resulted rankings from the four algorithms, an overall ranking of the candidate genes was achieved.

2.7. Statistical Analysis of Selected Genes. Genes of interest were identified, and the $\log 2$ values of the measured fluorescent intensities returned by the Partek software were back calculated to linear values. Then, means of all values of the same gene generated by different probes were calculated, if at least three values existed excluding outliers. Subsequently, standard deviations were calculated for the means and an unpaired $t$-test with Welch correction was performed using Excel 2011 ( $t$-test, tails 2, type 3) to obtain statistical significance.

\section{Results}

The aim of our study was to identify a group of genes that show a stable, nonchanging expression profile in immune cells under altered gravity conditions over a time range of seconds until several minutes. Therefore, we performed experiments on the 19th DLR PFC and the sounding rocket mission TEXUS-49, two platforms that offer microgravity times of 20 seconds and 6 minutes, respectively. During both missions, U937 cells, a model for monocytic/macrophageal cells of the human immune system, were exposed to different gravity conditions for various time periods (see Table 1). During the 19th DLR PFC, cells were exposed only to the first parabola with the following sequence: $1 \mathrm{~g}$ in-flight control, $1.8 \mathrm{~g}$, and microgravity $(\mu \mathrm{g})$. Cells were subjected to altered gravity conditions of $1.8 \mathrm{~g}$ and $\mu \mathrm{g}$ for 20 seconds in each case and were immediately fixed and stored cooled until RNA isolation. In case of the TEXUS-49 campaign, cells underwent 


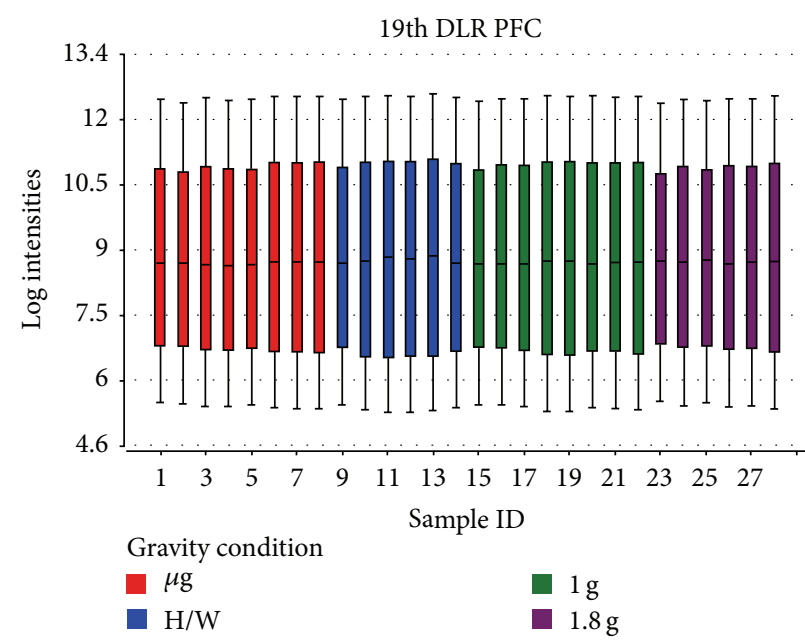

(a)

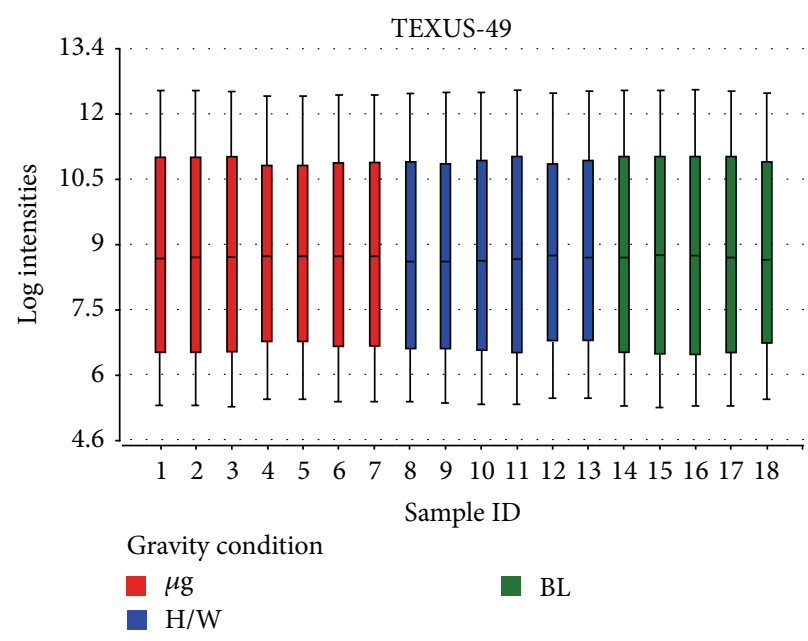

(b)

FIGURE 1: Boxplots showing the log expression values of individual microarrays. The central line represents the 50th percentile or median, whereas the upper and lower boundaries of the box display the 75th and 25th percentile, respectively. The upper and lower bars represent the 9th and the 91st percentile. Two experimental data sets are displayed, (a) 28 microarrays hybridized with samples from the 19th DLR PFC (8x $\mu \mathrm{g}, 6 \mathrm{x} \mathrm{H} / \mathrm{W}, 8 \mathrm{x} 1 \mathrm{~g}, 6 \mathrm{x} 1.8 \mathrm{~g}$ ) and (b) 18 microarrays hybridized with samples originating from the TEXUS-49 campaign (7x $\mu \mathrm{g}, 6 \mathrm{x}$ H/W, 5x $1 \mathrm{~g})$. The expression data show an even distribution for the displayed log intensities.

TABLE 1: Gravity conditions 19th DLR PFC and TEXUS-49.

\begin{tabular}{lcc}
\hline Gravity condition & 19th DLR PFC & TEXUS-49 \\
\hline $\begin{array}{l}\text { 1 g ground controls } \\
\text { (hardware; H/W })\end{array}$ & $\mathrm{H} / \mathrm{W}$ & $\mathrm{H} / \mathrm{W}$ \\
$\begin{array}{l}\text { Microgravity } \\
1 \mathrm{~g} \text { in-flight control }\end{array}$ & $\mu \mathrm{g}(20 \mathrm{sec})$ & $\mu \mathrm{g}(378 \mathrm{sec})$ \\
$\begin{array}{l}\text { In-flight baseline (hyper-g } \\
\text { phase directly before } \mu \mathrm{g} ;\end{array}$ & $1.8 \mathrm{~g}(20 \mathrm{sec})$ & $\mathrm{BL}(1 \mathrm{~g}-\max$. \\
$\mathrm{BL})$ & & $13.5 \mathrm{~g} ; 75 \mathrm{sec})$ \\
\hline
\end{tabular}

the following sequence of altered gravity: hypergravity up to $13.5 \mathrm{~g}$ during the first 75 seconds after liftoff and $\mu \mathrm{g}$ for 378 seconds. Hypergravity is defined as the baseline (BL), because samples mirror the vibration and hypergravity effects directly before the microgravity phase. In both experimental setups, on ground $1 \mathrm{~g}$ hardware controls $(\mathrm{H} / \mathrm{W})$ were performed to be able to differentiate between the effects caused by the conditions experienced before hypergravity and $\mu \mathrm{g}$ and the altered gravity conditions themselves. After the campaigns, the RNA samples were analyzed for quantity and quality by NanoDrop spectrophotometry and a bioanalyzer analysis, and only samples with an RNA integrity number (RIN) higher than 8.7 were chosen for subsequent microarray analysis. $12 \times 135 \mathrm{~K}$ Roche NimbleGen arrays were hybridized and data were collected after the normalization procedure. In total, we obtained data from 46 single microarrays (19th DLR PFC: $8 \mathrm{x} \mu \mathrm{g}, 6 \mathrm{x} \mathrm{H} / \mathrm{W}, 8 \mathrm{x} 1 \mathrm{~g}$, and 6x $1.8 \mathrm{~g}$; TEXUS-49: 7x $\mu \mathrm{g}$, $6 \mathrm{x} \mathrm{H} / \mathrm{W}$, and $5 \mathrm{x} \mathrm{BL})$.

Data tables were compiled individually for the 19th DLR PFC and TEXUS-49 including all gravity conditions listed in Table 1, and a first overview of the datasets was provided by a boxplot diagram (Figures 1(a) and 1(b)). Boxplots are a useful tool to visualize the variation within a microarray and between microarrays. The central line shows the position of the median, while the upper and the lower boundaries represent the upper (75th percentile) and lower (25th percentile) quartile. The ends of the tails display the 9th and the 91st percentile. The boxplots of the microarray data show that there is only little variation within a single array and between the arrays that belong to the same gravity condition. Figure 1 shows that the quality of both data sets (19th DLR PFC and TEXUS-49) is sufficient to proceed with further analyses.

In search of potential reference genes for gravitational studies in this monocytic/macrophageal cell system, we first performed PubMed database search to identify commonly used reference genes in RNA expression analyses in human cells. We found 22 genes that were used in several reverse transcription quantitative real-time PCR (RT-qPCR) studies as control genes for normalization (Table 2, supplementary Table 2). The microarray data tables were screened for these 22 widely used reference genes, and 20 of them could be located on the Roche NimbleGen $12 \times 135 \mathrm{~K}$ array that was used in our experiments. Two genes coding for $5 \mathrm{~s}$ and $18 \mathrm{~s}$ rRNAs could not be identified, since they are not spotted on the array. The PFC and TEXUS data sets were screened for those 20 selected potential reference genes, and fluorescence intensities were compiled for each gene and each gravity condition in heatmaps (Figures 2(a) and 2(b)). Overall fluorescence intensities for all samples showed only minor differences in the heatmaps. A more detailed visual inspection revealed completely equal fluorescence intensities for ACTB, ALB, B4GALT6, HMBS, HPRT1, PPIA, RPLP0, and YWHAZ for the gravity conditions prevailing during the 19th DLR PFC (Figure 2(a)). The gravity conditions investigated during the TEXUS-49 campaign showed stable expression values for the genes ACTB, ALB, B4GALT6, GUSB, PLA2G4A, POLR2A, PPIA, TBP, UBC, and YWHAZ (Figure 2(b)). For further characterization and identification of stable reference genes, 
TABLE 2: List of potential reference genes.

\begin{tabular}{|c|c|c|}
\hline Potential reference gene & $\begin{array}{l}\text { Gene } \\
\text { symbol }\end{array}$ & Citation \\
\hline 5s rRNA & & {$[85]$} \\
\hline 18s rRNA & & [86] \\
\hline$\beta$-Actin & ACTB & {$[49,51]$} \\
\hline Albumin & ALB & [49] \\
\hline$\beta-2$ microglobin & $\mathrm{B} 2 \mathrm{M}$ & {$[49,51,56]$} \\
\hline $\begin{array}{l}\text { UDP-Gal:bGlcNAcb } \\
\text { 1,4-galactosyl-transferase, } \\
\text { polypeptide } 6\end{array}$ & B4GALT6 & {$[86]$} \\
\hline $\begin{array}{l}\text { Glucose 6-phosphate } \\
\text { dehydrogenase }\end{array}$ & G6PD & [49] \\
\hline $\begin{array}{l}\text { Glyceraldehyde-3-phosphate } \\
\text { dehydrogenase }\end{array}$ & GAPDH & $\begin{array}{l}{[49,51,56,85} \\
87,88]\end{array}$ \\
\hline Glucuronidase, beta & GUSB & {$[86]$} \\
\hline $\begin{array}{l}\text { Hydroxymethylbilane synthase } \\
\text { (porphobilinogen deaminase) }\end{array}$ & HMBS & {$[49,51,56]$} \\
\hline $\begin{array}{l}\text { Hypoxanthine } \\
\text { phosphoribosyltransferase } 1\end{array}$ & HPRT1 & {$[49,51,56,86]$} \\
\hline Heat shock protein $90 \mathrm{kDa}$ & HSP90AA1 & [86] \\
\hline Phospholipase A2 & PLA2G4A & [49] \\
\hline RNA polymerase II & POLR2A & {$[49,86]$} \\
\hline $\begin{array}{l}\text { Peptidylprolyl isomerase A } \\
\text { (Cyclophilin A) }\end{array}$ & PPIA & {$[49,86]$} \\
\hline Ribosomal protein L13 & RPL13A & {$[49,51,56,86]$} \\
\hline $\begin{array}{l}\text { Acidic ribosomal } \\
\text { phosphoprotein P0 }\end{array}$ & RPLP0 & [89] \\
\hline $\begin{array}{l}\text { Succinate dehydrogenase } \\
\text { complex, subunit A }\end{array}$ & SDHA & {$[51,56,86]$} \\
\hline TATA box binding protein & TBP & {$[49,51,56,86]$} \\
\hline$\alpha$-Tubulin & TUBA1 & [49] \\
\hline Ubiquitin $\mathrm{C}$ & $\mathrm{UBC}$ & {$[51,56]$} \\
\hline $\begin{array}{l}\text { Tyrosine } 3 \text {-monooxygenase } \\
\text { tryptophan 5-monooxygenase } \\
\text { activation protein }\end{array}$ & YWHAZ & {$[51,56,86]$} \\
\hline
\end{tabular}

we performed a geNorm pilot study [51] and calculated the coefficient of variation (CV) for all 20 potential reference genes (Figure 3). For homogeneous groups, CV values below $25 \%$, and for heterogeneous groups, CV values below $50 \%$ are acceptable [56]. Rapid and extreme changes in gravity induce strong changes in cellular functions. Therefore, we classified our samples as heterogeneous groups. According to the set criteria, all analyzed potential reference genes showed CV values below $50 \%$ for the PFC and TEXUS data sets (Figures $3(\mathrm{a})$ and 3(b)). In the sample set of the 19th DLR PFC, all genes but HMBS fulfill even the more stringent criterion of a CV below 25\% (Figure 3(a)). For the samples collected during the TEXUS-49 campaign, all genes but HPRT1 and PLA2G4A display CV values below 25\% (Figure 3(b)).

To increase the number of potential reference genes that can be used as standards for differential expression analyses in gravitational studies, we extended our analysis to evolutionary highly conserved genes. We hypothesized that

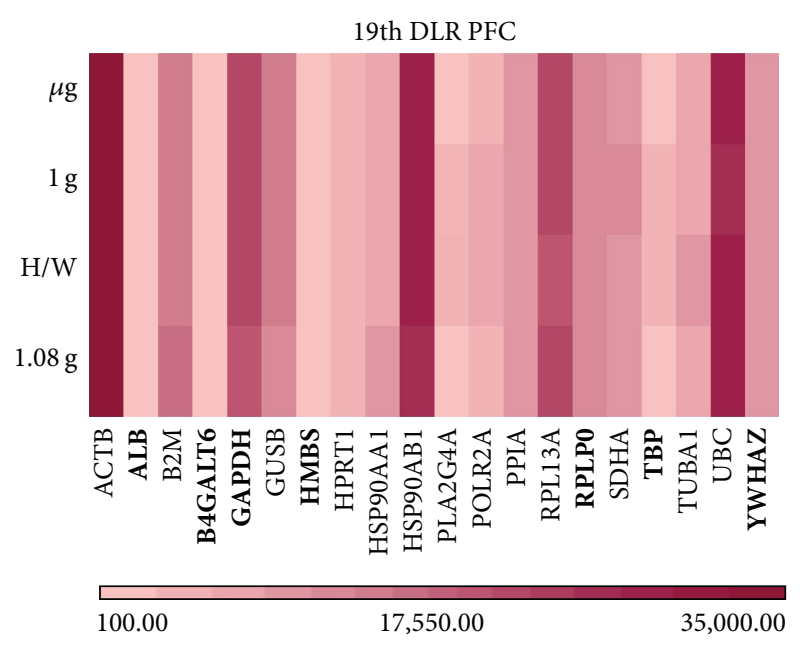

(a)

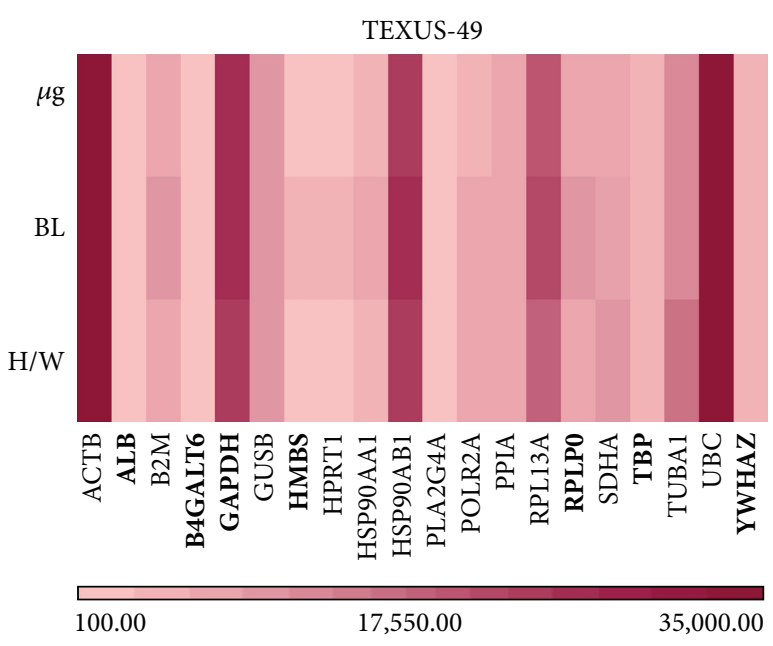

(b)

FIGURE 2: Heatmaps for selected reference genes. The graph illustrates fluorescent intensity levels of the 20 potential reference genes from Table 2 between the three and four different gravity conditions, respectively. Each gene is represented in one column, and each gravity condition is represented in one row. (a) $\mu \mathrm{g}, \mathrm{H} / \mathrm{W}, 1 \mathrm{~g}$, and $1.8 \mathrm{~g}$ (19th DLR PFC) and (b) H/W, BL, and $\mu$ g (TEXUS-49). The heatmap shows large variation in fluorescence intensities for the different genes. However, within the same gene, expression levels are similar for all tested conditions. The lower bar with the graduated red colors is the measure for the different fluorescence intensities.

genes stable over time and taxonomic kingdoms should have very fundamental functions within a cell and thus be largely independent from external influences to ensure basic cellular functions. Besides ribosomal RNA genes, which are not represented on the microarray applied in this study, $\mathrm{ABC}$ transporters and tRNA genes are also evolutionary highly conserved over a wide variety of organisms. Unfortunately, the $12 \times 135 \mathrm{~K}$ Roche NimbleGen array does also not contain probes for tRNA. Therefore, we had a look at expression profiles of $\mathrm{ABC}$ transporters and tRNA related genes (supplementary Tables 2 and 3). Since almost all fluorescence values of tRNA related genes showed a high variance making 


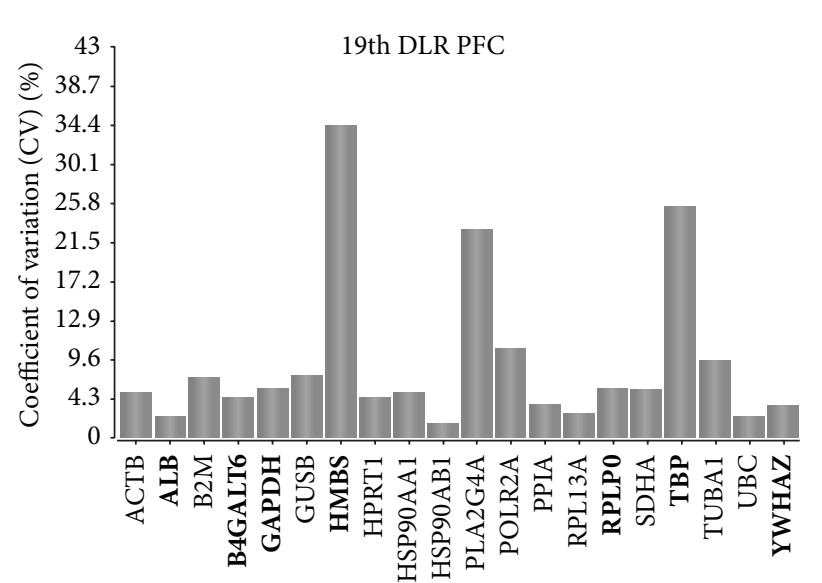

(a)

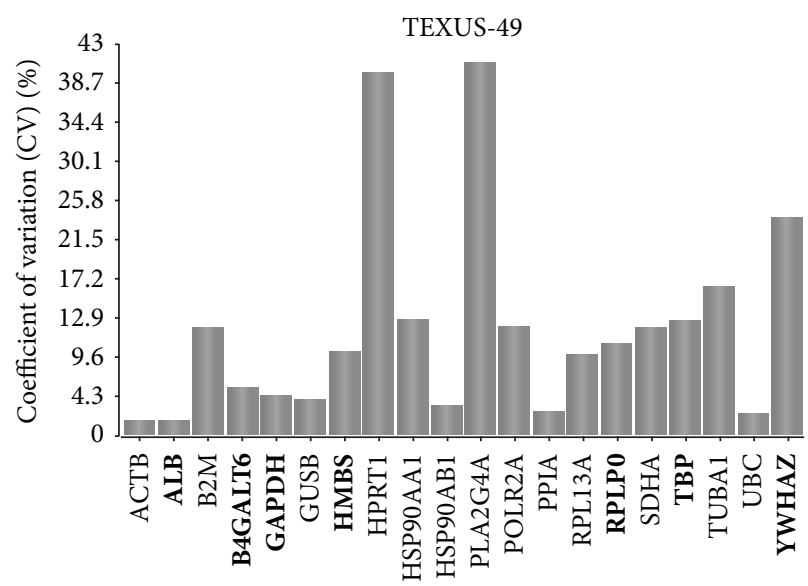

(b)

Figure 3: Coefficient of variation calculation for the potential reference genes. This bar chart displays the coefficient of variation (CV) in \% of the 20 potential reference genes across the gravity conditions for the 19th DLR PFC (H/W, $1 \mathrm{~g}, 1.8 \mathrm{~g}, \mu \mathrm{g})$ and TEXUS-49 (H/W, BL, $\mu \mathrm{g})$. A lower value corresponds to higher stability in gene expression. (a) 19th DLR PFC: All calculated CV values are below the threshold of 50\%. (b) TEXUS-49: all CV values are below 50\%, but in total more genes show higher coefficients of variation.

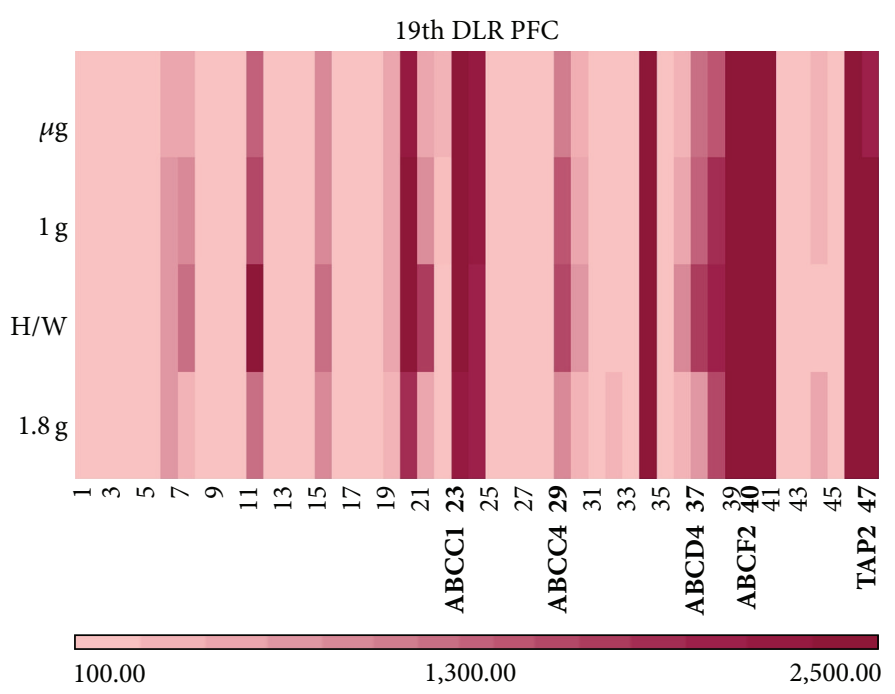

(a)

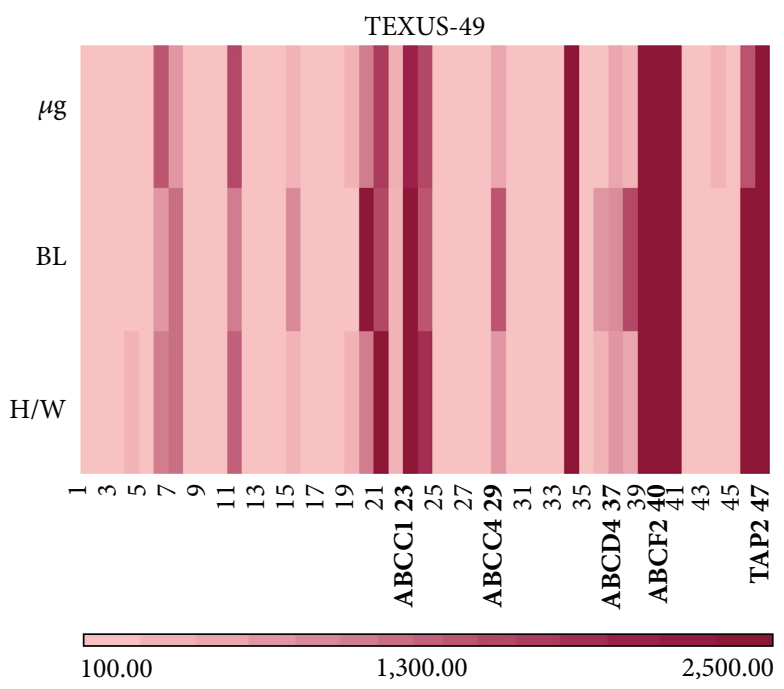

(b)

FIGURE 4: Heatmaps for highly conserved $\mathrm{ABC}$ transporters. The fluorescent intensity levels of the $47 \mathrm{ABC}$ transporter genes shown in supplementary Table 2 were quantified for the different gravity conditions. Each gene is represented in one column, and each gravity condition is represented in one row. (a) $\mu \mathrm{g}, 1 \mathrm{~g}, \mathrm{H} / \mathrm{W}$, and $1.8 \mathrm{~g}$ (19th DLR PFC) and (b) $\mu \mathrm{g}$, BL, and H/W (TEXUS-49). The heatmaps show large variation in fluorescence intensities for the different genes. However, within the same gene, expression levels are mostly similar for all tested conditions. The lower bar with the graduated red colors is the measure for the different fluorescence intensities.

reasonable analysis impossible, we concentrated on the $\mathrm{ABC}$ transporters. Heatmap analyses were carried out to obtain a first impression on the gene stability (Figure 4 ). The samples from the 19th DLR PFC and TEXUS-49 mission also show a rather high variation in fluorescence intensities (Figures 4(a) and 4(b)). The calculation of the CV for these samples (Figure 5) displays higher values compared to the potential reference genes; however, taken together all analyzed samples of the 19th DLR PFC fulfill the criterion of CV values less than $50 \%$ in case of $A B C$ transporter signals (Figure 5(a)). Out of 47 samples, 36 are also below 25\% CV. Although three samples from TEXUS- 49 showed values above $50 \% \mathrm{CV}$
(Figure 5(b)), 37 samples stayed below the 25\% threshold (Figure 5(b)). Selected reference genes and $\mathrm{ABC}$ transporters (marked in bold, Figures 4 and 5) were chosen for further detailed analysis of differential gene expression under altered gravity conditions.

For nine of the potential reference genes from the literature, there were at least three values returned by the microarray, generated by independent probes targeting the same gene. Two of these genes were excluded from further analysis due to high variance between their single values (HSP90AA1 and PPIA), and the remaining seven genes (ALB, B4GALT6, GAPDH, HMBS, RPLP0, TBP, and YWHAZ (see 


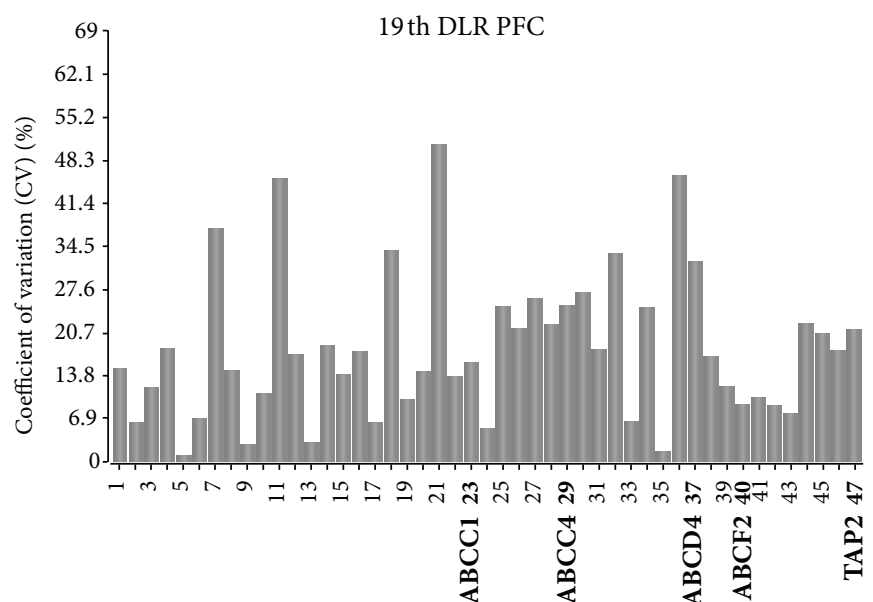

(a)

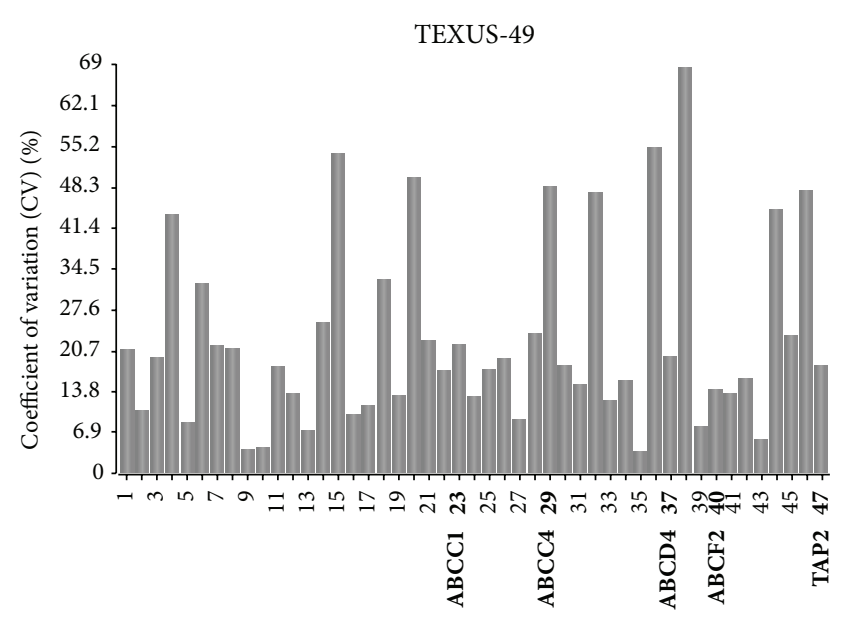

(b)

Figure 5: Coefficient of variation calculation for the ABC transporter genes. This bar chart displays the coefficient of variation (CV) in \% of the $47 \mathrm{ABC}$ transporter genes across the gravity conditions for the 19th DLR PFC (H/W, $1 \mathrm{~g}, 1.8 \mathrm{~g}, \mu \mathrm{g})$ and TEXUS-49 (H/W, BL, $\mu \mathrm{g})$. A lower value corresponds to higher stability in gene expression. (a) 19th DLR PFC: all calculated CV values are below the threshold of 50\% and fulfill the criterion. (b) TEXUS-49: three genes show CV values higher than $50 \%$ and were excluded from further analyses. The numbers correspond to the $\mathrm{ABC}$ transporters listed in supplementary Table 2. Genes that were further analyzed are labeled and marked in bold (ABCC1, $\mathrm{ABCC} 4$, $\mathrm{ABCD} 4, \mathrm{ABCF} 2$, and TAP2).

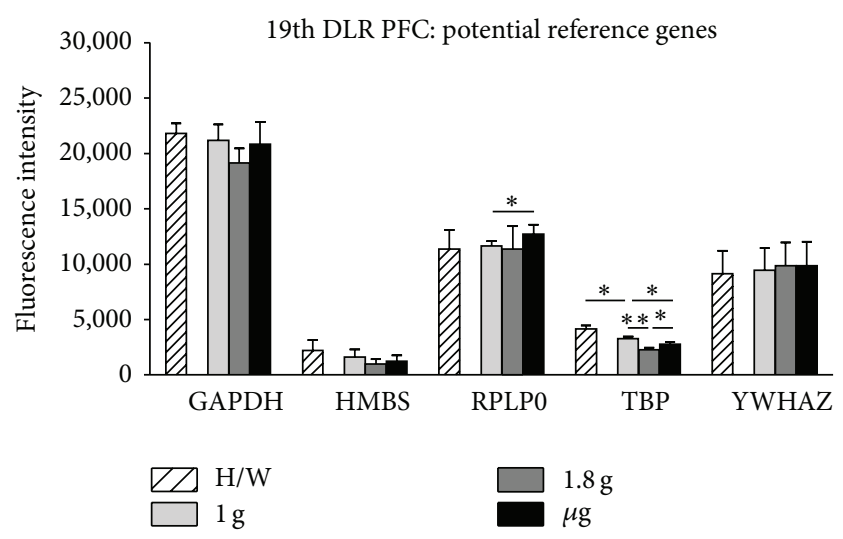

(a)

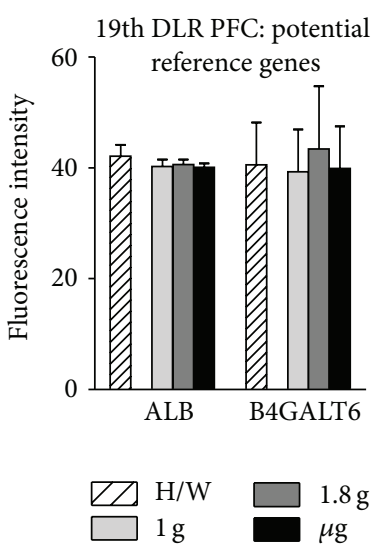

(b)

Figure 6: Influence of altered gravity during parabolic flight on potential reference genes. RNA expression levels after $1 \mathrm{~g}$ (light gray), $1.8 \mathrm{~g}$ (dark gray), and $\mu \mathrm{g}$ (black) conditions during the 19th DLR parabolic flight campaign. Hardware ground controls (H/W, striped) are shown for each experimental group. RNA expression levels are shown as fluorescence intensities. (a) The expression values for GAPDH, HMBS, RPLP0, TBP, and YWHAZ are displayed. (b) ALB and B4GALT6 show low but stable fluorescent intensities. GAPDH, HMBS, YWHAZ, ALB, and B4GALT6 show no significant change in RNA levels upon altered gravity for $20 \mathrm{sec}$, while RPLP0 displays $\mu$ g sensitivity compared to $1 \mathrm{~g}$ and TBP reacts sensitively to all $\mathrm{g}$ conditions. Mean values of at least three measurements with standard deviations are shown. ${ }^{*} P<0.05$, ${ }^{* *} P<0.005$.

Table 3)) were subjected to further statistics. The calculation of the mean fluorescence intensity levels revealed that different ranges of transcript abundance are present in both experimental setups. While ALB and B4GALT6 seem to be expressed rather low, GAPDH, HMBS, RPLP0, TBP, and YWHAZ are represented in much higher abundance (Figures 6 and 7). The comparison of mean fluorescence intensities of one gene under different g conditions revealed that GAPDH, HMBS, YWHAZ, ALB, and B4GALT6 are stably expressed with respect to all investigated gravity conditions during parabolic flight of the 19th DLR PFC (Figures 6(a) and 6(b)).
RPLP0 is significantly upregulated by $\mu \mathrm{g}$ compared to $1 \mathrm{~g}$, while TBP is initially downregulated by $1.8 \mathrm{~g}$ and recovers during $\mu \mathrm{g}$ (Figure 6(a)). Furthermore, comparison of inflight $1 \mathrm{~g}$ controls to $1 \mathrm{~g}$ ground controls (H/W) shows a significantly reduced mRNA level of TBP portending that during the preexperimental phase a certain kind of stress was accumulated in the cells influencing its expression level.

The data analysis of the TEXUS-49 sounding rocket experiment reveals stable RNA expression levels throughout the different $g$ levels for GAPDH, HMBS, RPLP0, YWHAZ, ALB, and B4GALT6 (Figures 7(a) and 7(b); Table 4, and 


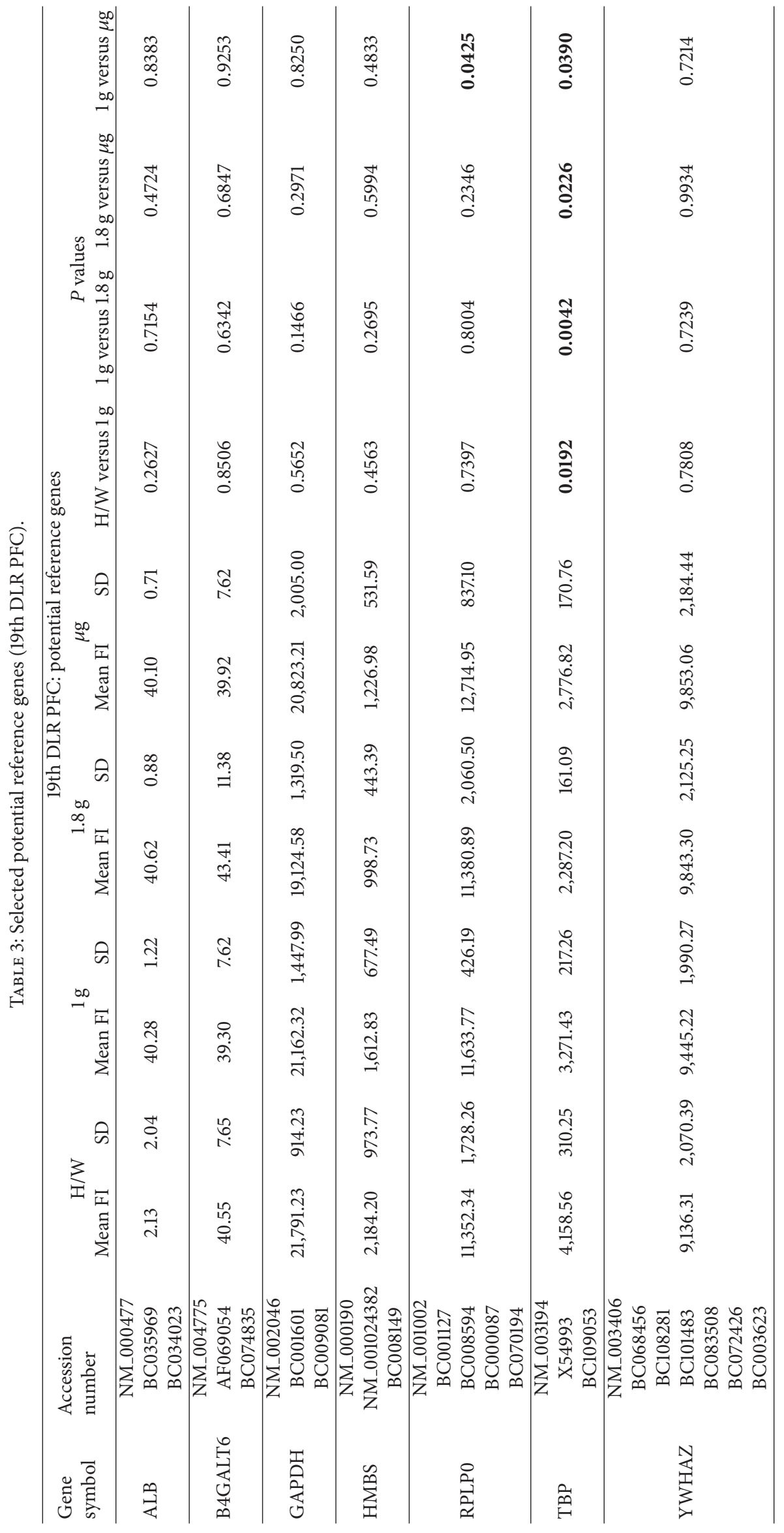




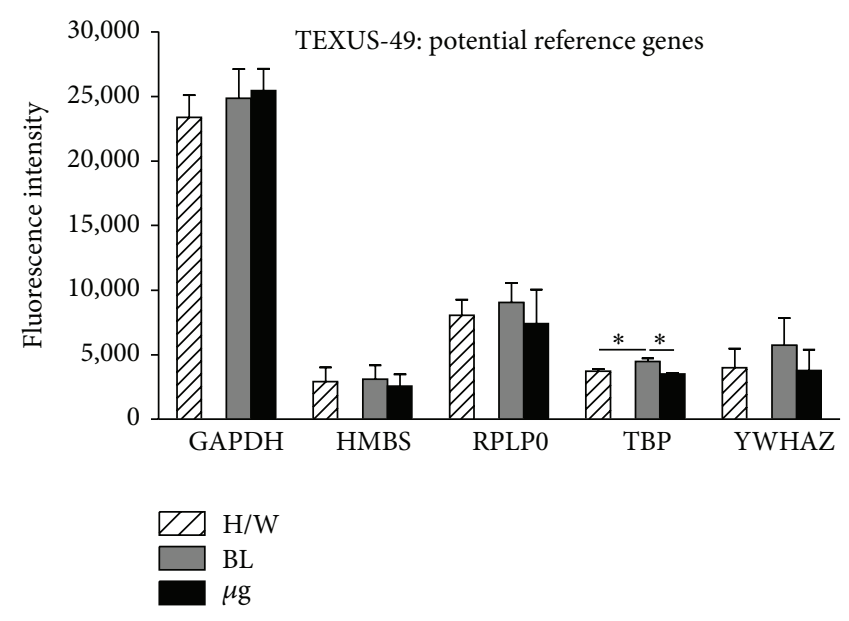

(a)

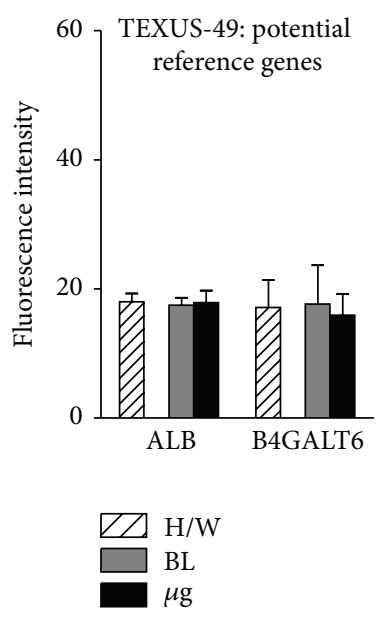

(b)

FIGURE 7: Influence of altered gravity during sounding rocket flight on potential reference genes. GAPDH, HMBS, RPLP0, TBP, and YWHAZ (a), ALB and B4GALT6 (b) RNA expression levels after launch and acceleration (BL, dark gray) and $\mu \mathrm{g}$ (black) conditions of TEXUS-49. Hardware ground controls (H/W, striped) are shown for each experimental group. RNA levels are displayed as fluorescence intensities. GAPDH, HMBS, RPLP0, YWHAZ, ALB, and B4GALT6 show no significant change in RNA levels upon altered gravity, while TBP reacts sensitively to all g conditions. Mean values of at least three measurements with standard deviations are shown. ${ }^{*} P<0.05$.

supplementary Table 1). TBP RNA levels were reduced in $\mu \mathrm{g}$ samples compared to the in-flight BL. Interestingly, comparisons between the $\mathrm{H} / \mathrm{W}$ ground controls and BL revealed a postlaunch increase in RNA expression most likely induced by the launch vibrations or hypergravity (Figure $7(a)$ ).

Only a very low number of tRNA related genes fulfilled our criterion of being represented by at least three probes (four out of 32). For three out of those four genes, fluorescent intensity showed a great variance between the single values as mentioned above. Only one tRNA synthetase (SARS) yielded reasonable results. The exposure of the cells to altered gravity conditions during the parabolic flight resulted in a decreased SARS expression in $1 \mathrm{~g}$ in-flight control and $1.8 \mathrm{~g}$ samples compared to the H/W ground control and $1 \mathrm{~g}$ control, respectively (supplementary Table 3 ). Although not significant, there is a visible increase of SARS mRNA upon $\mu \mathrm{g}$ compared to $1.8 \mathrm{~g}$ arguing for an immediate expression recovery after termination of $1.8 \mathrm{~g}$. This is in line with the results from TEXUS-49 flight campaign where SARS shows no significant expression change in in-flight baseline control or in $\mu \mathrm{g}$ compared to $\mathrm{H} / \mathrm{W}$ ground control. This could be due to fast expression recovery of the gene during $g$ alterations, hyper-g phase, and $\mu \mathrm{g}$.

The highly conserved $\mathrm{ABC}$ transporters were represented as a large group of genes on the applied microarray. We analyzed a total of $47 \mathrm{ABC}$ transporters belonging to nine different sub-families (supplementary Table 2). 19 ABC transporter genes were represented by three or more individual probes on the microarray and 11 of them had similar fluorescent intensities meeting the requirements for a statistical analysis. Exemplarily, five of those $11 \mathrm{ABC}$ transporters are shown in Figures 8 and 9.

During the short-term gravity alterations achieved by parabolic flights, $\mathrm{ABCC} 1$ and $\mathrm{ABCF} 2$ displayed no significant differential expression between all $\mathrm{g}$ conditions analyzed. TAP2 showed a significant reduction of RNA expression

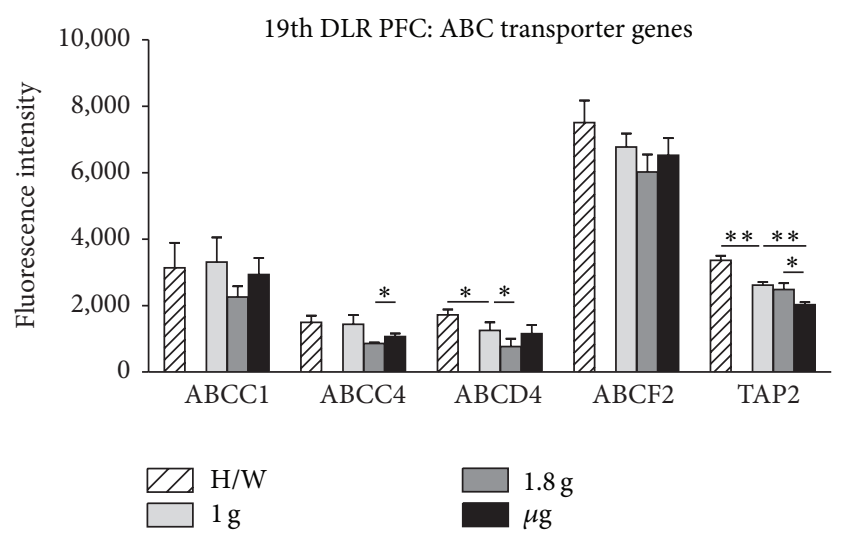

FIGURE 8: Influence of altered gravity during parabolic flight on $\mathrm{ABC}$ transporter genes. ABCC1, ABCC4, ABCD4, ABCF2, and TAP2 RNA levels after $1 \mathrm{~g}$ (light gray), $1.8 \mathrm{~g}$ (dark gray), and $\mu \mathrm{g}$ (black) conditions during the 19th DLR parabolic flight campaign. Hardware ground controls (H/W, striped) are shown for each experimental group. RNA expression levels are displayed as fluorescence intensities. $\mathrm{ABCC} 1$ and $\mathrm{ABCF} 2$ show no significant change in RNA expression levels upon altered gravity, while ABCC4 and TAP2 display $\mu \mathrm{g}$ sensitivity compared to $1.8 \mathrm{~g}$ and to $1.8 \mathrm{~g}$ and $1 \mathrm{~g}$, respectively. $\mathrm{ABCD} 4$ reacts sensitively to $1.8 \mathrm{~g}$ compared to $1 \mathrm{~g}$, and $\mathrm{ABCD} 4$ and TAP2 show vibration sensitivity comparing $1 \mathrm{~g}$ to $\mathrm{H} / \mathrm{W}$. Mean values of at least three measurements with standard deviations are shown. ${ }^{*} P<0.05,{ }^{* *} P<0.005$.

comparing $\mu \mathrm{g}$ samples to $1.8 \mathrm{~g}$ samples, while $\mathrm{ABCC} 4$ showed an increase. ABCD4 revealed hyper-g sensitivity by reducing its RNA level during $1.8 \mathrm{~g}$ compared to $1 \mathrm{~g}$. And $\mathrm{ABCD} 4$ and TAP2 displayed reduced expression during preflight phase compared to H/W control (Figure 8, Table 5).

A prolonged exposure of the cells to $\mu \mathrm{g}$ ( $378 \mathrm{sec}$ versus $20 \mathrm{sec}$ ) during TEXUS- 49 experiment led to significant reduction of mRNA levels of $\mathrm{ABCC} 4, \mathrm{ABCD} 4, \mathrm{ABCF} 2$, and 


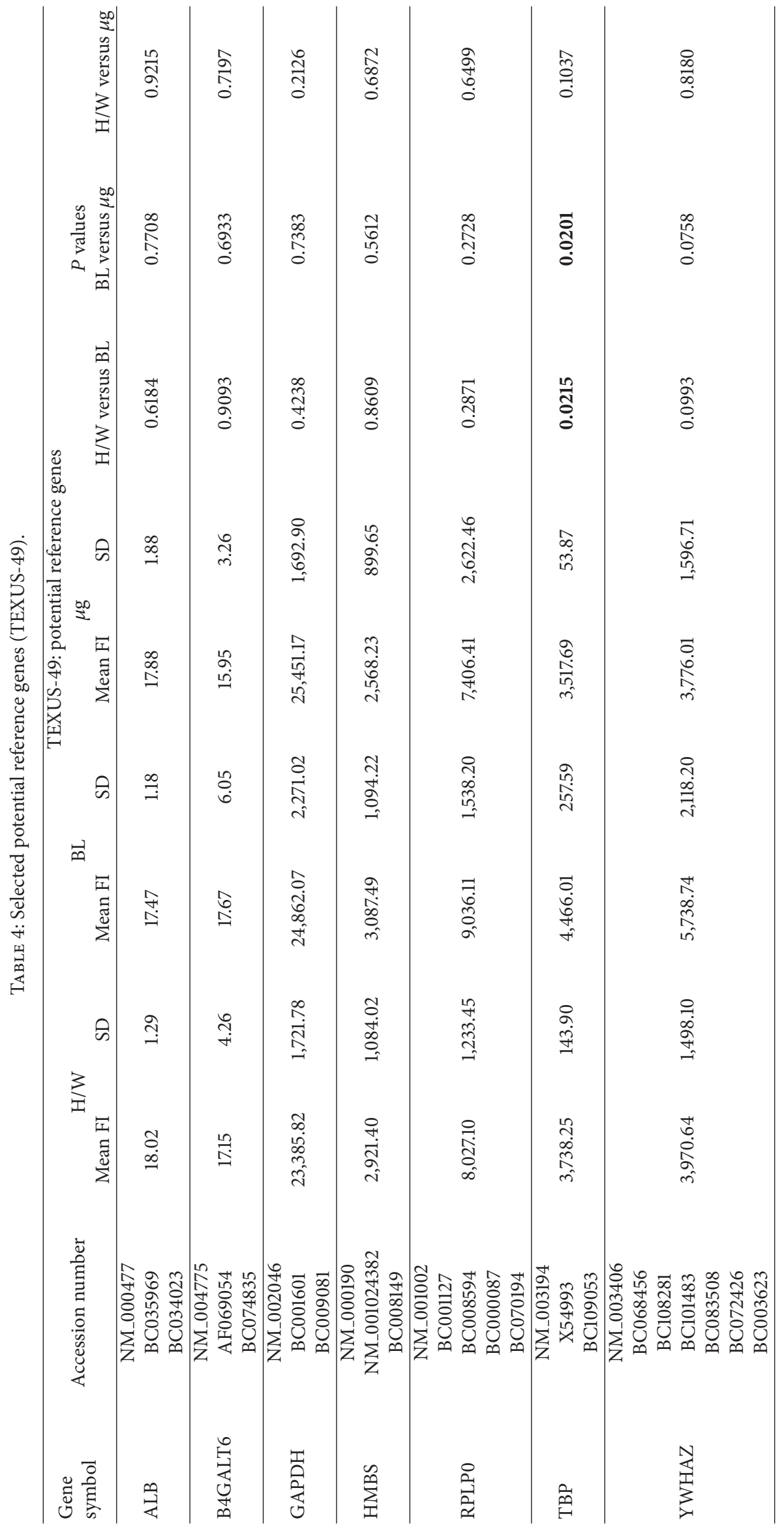




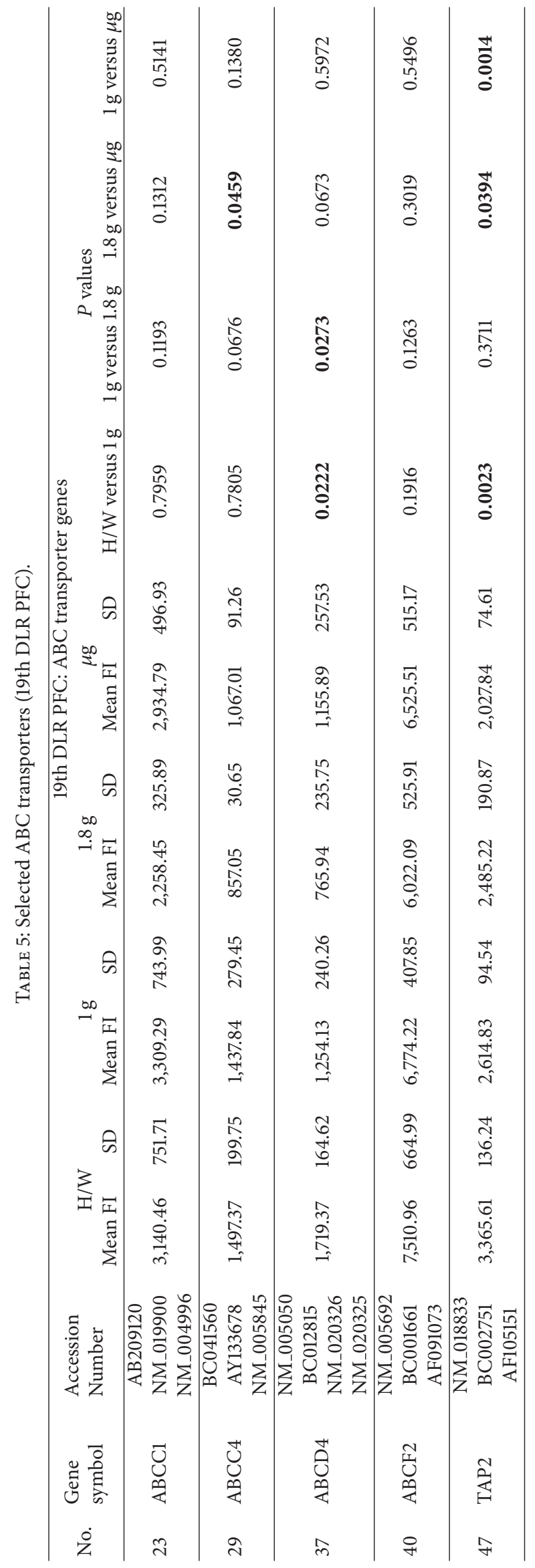




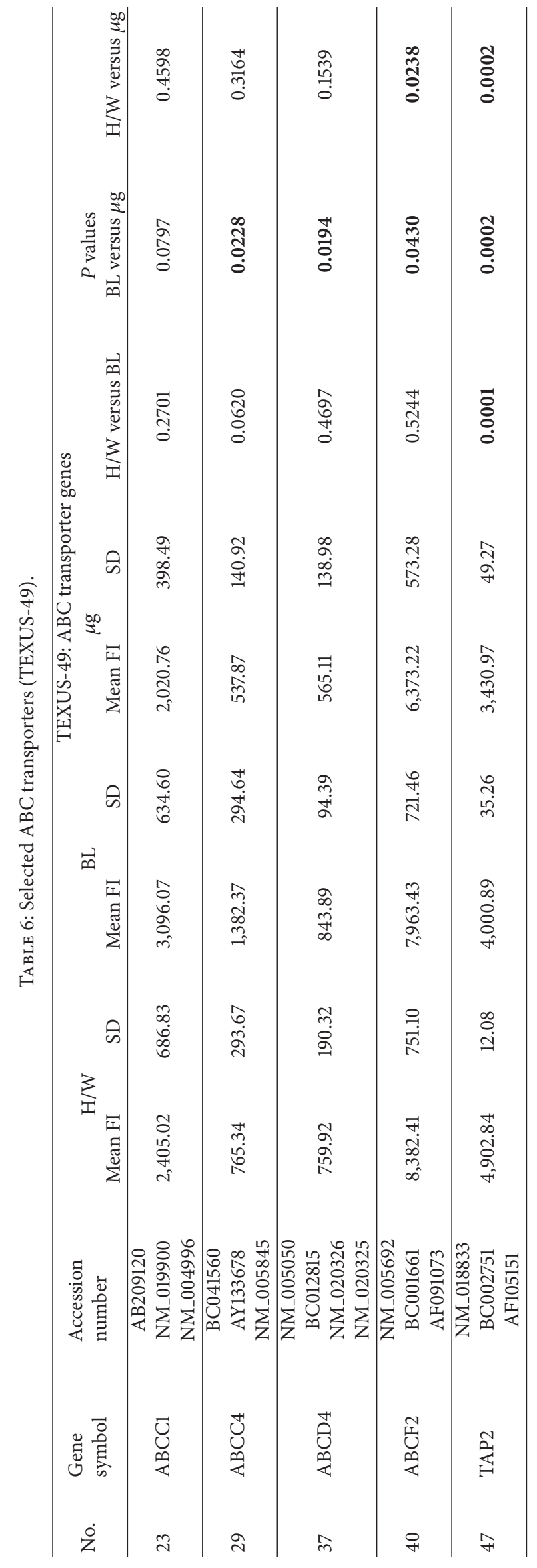




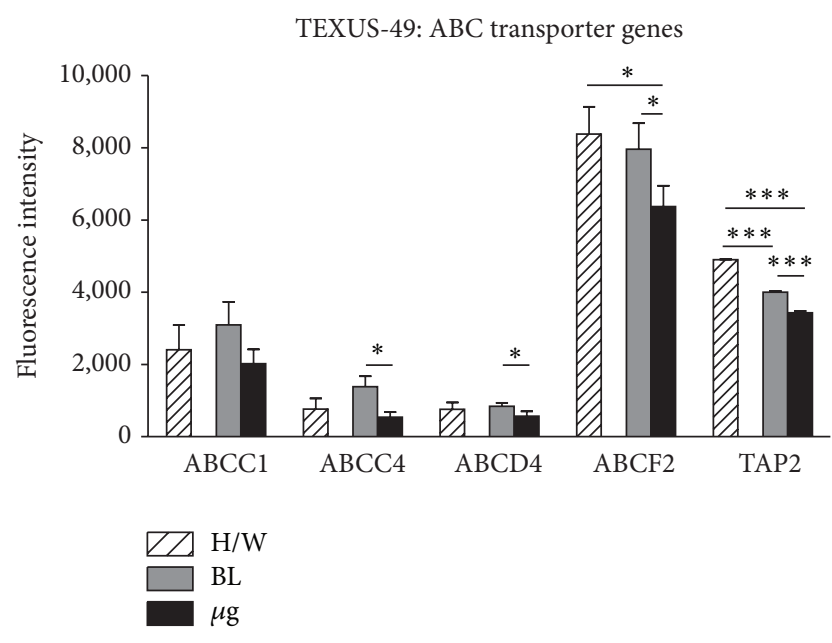

FIGURE 9: Influence of altered gravity during sounding rocket flight on $\mathrm{ABC}$ transporter genes. $\mathrm{ABCC} 1, \mathrm{ABCC} 4, \mathrm{ABCD} 4, \mathrm{ABCF} 2$, and TAP2 RNA expression levels after launch and acceleration (BL, dark gray) and $\mu$ g (black) conditions of TEXUS-49. Hardware ground controls (H/W, striped) are shown for each experimental group. RNA levels are depicted as fluorescence intensities. Only ABCC1 expression is stable over all g conditions. ABCC4, ABCD4, ABCF2, and TAP2 display $\mu \mathrm{g}$ sensitivity compared to $\mathrm{BL}$ and to $\mathrm{H} / \mathrm{W}$ in the case of ABCF2 and TAP2. TAP2 also shows vibration sensitivity comparing $\mathrm{BL}$ to $\mathrm{H} / \mathrm{W}$. Mean values of at least three measurements with standard deviations are shown. ${ }^{*} P<0.05,{ }^{* *} P<0.005$, and ${ }^{* * *} P<0.0005$.

TAP2 in $\mu$ g compared to in-flight BL. Furthermore, TAP2 expression already decreases in the first phase after launch (BL versus $\mathrm{H} / \mathrm{W}$ ), while the other $\mathrm{ABC}$ transporters' mRNA levels appeared stable (Figure 9, Table 6).

Taken together, in this study, we identified eight genes as nonchanging reference genes suitable for studies under altered gravity conditions, and nine genes as candidates for g-sensitivity and 83 genes could not be assigned to either group due to low probe number on the microarray or to great variance between the probe values (Table 7 ).

\section{Discussion}

Microarray expression data are intensely used to analyze differential gene expression in cells, tissues, and organisms that are exposed to various conditions [29, 30]. Even in the field of gravitational biology, gene expression analyses are utilized with increasing frequency. Recently, an article was released giving an overview of all published microarray based microgravity studies [57] describing the difficulties to combine and overlay the data from different experiments, study objects, microgravity platforms (simulated microgravity, sounding rocket, space shuttle, and ISS missions), and different microarray experimental designs [58-64]. The different analyses were done mostly in simulated microgravity and investigated various organisms and cell types like Arabidopsis thaliana, Salmonella enterica, and rat and mouse tissues, as well as human osteoblasts and T-cells [58-61, 6570] (for the complete list see [57]). The goal was to screen the vast amount of data to identify a list of major "space genes" that are sensitive to microgravity throughout all involved platforms. The data inspection revealed a huge number of differentially expressed genes but with only little or no overlap between closely related studies on the level of single genes. In contrast, on the level of pathway analysis, it was possible to define major pathways like ECM-receptor interaction, focal adhesion, TGF-beta signaling, and glycolysis being affected in many species (human, mouse, rat, and Xenopus, in different combinations) by the exposure to microgravity [57]. Moreover, major "space genes" sensitive to microgravity were defined, if they were found to be differentially expressed in at least four of the examined studies. The results showed in total eight potential space genes (CD44, MARCKS, FN1, TUBA1, CTGF, CYR61, MT2, and MT1), which are involved in T-cell development, cell motility, extracellular matrix components, cytoskeleton, and oxidative stress protection [57]. The study describes in detail the difficulties of combining gene expression data from different groups due to varying experimental setups and conditions. It elucidates that it is of high relevance to be able to standardize gene expression data that arose from RT-qPCR or microarray studies. A key component for standardization within a single experiment and between different experiments is normalization. An important factor for normalization is the use of stable reference genes. There are numerous studies describing that commonly used reference genes could represent a pitfall, because they are often differentially expressed under specific experimental conditions and that they have to be considered carefully before the experiment [46-49]. Different guidelines have been published to facilitate standardized experimental design and increase comparability between analyses (MIQE, MIAME) $[34,39,40]$. It is, for example, highly recommended to perform a pilot study with programs like geNorm or BestKeeper prior to the experiment to identify several stable reference genes that can be used simultaneously as controls for normalization in the differential gene expression analysis $[50,51]$.

Alternatively, to microarrays a novel technique, RNA-Seq, is under development for whole genome expression analyses. It is reported that this method has advantages in detecting low abundance transcripts, genetic variants, and splice isoforms of genes as well as distinguishing biologically critical isoforms [71]. Despite the described technical advantages of RNASeq, microarrays remain popular for some reasons. The microarray platforms have a proven track record spanning nearly two decades in the lab. The arrays are generally considered easier to use with less complicated and less laborintensive sample preparation than RNA-Seq. The same holds true for the data storage and data analysis. Moreover, despite the rapid drop in the cost associated with next-generation sequencing (NGS), arrays are still more economical and yield higher throughput, providing significant advantages when working with a large number of samples. Therefore, microarray analyses are still more commonly used for transcriptional profiling experiments [71].

Taking into account that many other studies throughout the last few years have reported a considerable portion of the traditionally used reference genes not being stably expressed under various experimental conditions, it becomes rather 
TABLE 7: Overview of g-stable (+) and g-sensitive genes (-).

\begin{tabular}{|c|c|c|c|c|c|c|c|c|}
\hline \multirow{2}{*}{ Gene symbol } & \multirow{2}{*}{ Accession number } & \multicolumn{4}{|c|}{ 19th DLR PFC } & \multicolumn{3}{|c|}{ TEXUS-49 } \\
\hline & & $\begin{array}{c}(\mathrm{H} / \mathrm{W} \\
\text { versus 1g) }\end{array}$ & $\begin{array}{c}\text { (1 g versus } \\
1.8 \mathrm{~g})\end{array}$ & $\begin{array}{c}(1.8 \mathrm{~g} \\
\text { versus } \mu \mathrm{g})\end{array}$ & $\begin{array}{c}\text { (1 g versus } \\
\mu \mathrm{g})\end{array}$ & $\begin{array}{c}(\mathrm{H} / \mathrm{W} \\
\text { versus BL) }\end{array}$ & $\begin{array}{c}\text { (BL versus } \\
\mu \mathrm{g})\end{array}$ & $\begin{array}{c}(\mathrm{H} / \mathrm{W} \\
\text { versus } \mu \mathrm{g})\end{array}$ \\
\hline \multicolumn{9}{|c|}{ Potential reference genes } \\
\hline \multirow{4}{*}{ ALB } & NM_000477 & & & & & & & \\
\hline & BC035969 & + & + & + & + & + & + & + \\
\hline & ВC034023 & & & & & & & \\
\hline & NM_004775 & & & & & & & \\
\hline \multirow[t]{3}{*}{ B4GALT6 } & AF069054 & + & + & + & + & + & + & + \\
\hline & BC074835 & & & & & & & \\
\hline & NM_002046 & & & & & & & \\
\hline \multirow[t]{3}{*}{ GAPDH } & ВС001601 & + & + & + & + & + & + & + \\
\hline & BC009081 & & & & & & & \\
\hline & NM_000190 & & & & & & & \\
\hline \multirow[t]{4}{*}{ HMBS } & NM_001024382 & + & + & + & + & + & + & + \\
\hline & BC008149 & & & & & & & \\
\hline & NM_001002 & & & & & & & \\
\hline & ВC001127 & & & & & & & \\
\hline \multirow[t]{4}{*}{ RPLP0 } & ВC008594 & + & + & + & - & + & + & + \\
\hline & BC000087 & & & & & & & \\
\hline & BC070194 & & & & & & & \\
\hline & NM_003194 & & & & & & & \\
\hline \multirow[t]{5}{*}{ TBP } & X54993 & - & - & - & - & - & - & + \\
\hline & BC109053 & & & & & & & \\
\hline & NM_003406 & & & & & & & \\
\hline & BC068456 & & & & & & & \\
\hline & BC108281 & & & & & & & \\
\hline \multirow[t]{4}{*}{ YWHAZ } & BC101483 & + & + & + & + & + & + & + \\
\hline & BC083508 & & & & & & & \\
\hline & BC072426 & & & & & & & \\
\hline & BC003623 & & & & & & & \\
\hline \multicolumn{9}{|c|}{$\mathrm{ABC}$ transporter genes } \\
\hline \multirow{4}{*}{ ABCA5 } & NM_018672 & & & & & & & \\
\hline & AJ275973 & + & + & + & + & + & + & + \\
\hline & AY028897 & & & & & & & \\
\hline & NM_080283 & & & & & & & \\
\hline \multirow[t]{3}{*}{ ABCA9 } & ВС062472 & + & + & + & + & + & + & + \\
\hline & NM_172386 & & & & & & & \\
\hline & AB209120 & & & & & & & \\
\hline \multirow{3}{*}{ ABCC1 } & NM_019900 & + & + & + & + & + & + & + \\
\hline & NM_004996 & & & & & & & \\
\hline & BC041560 & & & & & & & \\
\hline \multirow[t]{3}{*}{ ABCC4 } & AY133678 & + & + & - & + & + & - & + \\
\hline & NM_005845 & & & & & & & \\
\hline & AK127951 & & & & & & & \\
\hline $\mathrm{ABCC} 12$ & NM_145187 & _- & & & & & & \\
\hline $\mathrm{ABCC} 12$ & NM_033226 & - & + & + & + & - & - & + \\
\hline & BC036378 & & & & & & & \\
\hline & NM_005050 & & & & & & & \\
\hline $\mathrm{ABCD} 4$ & $\begin{array}{c}\text { BC012815 } \\
\text { NM_020326 }\end{array}$ & - & - & + & + & + & - & + \\
\hline & NM_020325 & & & & & & & \\
\hline & NM_005692 & & & & & & & \\
\hline ABCF2 & ВC001661 & + & + & + & + & + & - & - \\
\hline & AF091073 & & & & & & & \\
\hline & NM_018833 & & & & & & & \\
\hline TAP2 & BC002751 & - & + & - & - & - & - & - \\
\hline & AF105151 & & & & & & & \\
\hline
\end{tabular}


apparent that a natural constant as $1 \mathrm{~g}$ might have even more an effect on the expression of genes than other test circumstances. Therefore, we focused in this study on the investigation of the expression qualities of several potential reference genes under $1 \mathrm{~g}$ compared to altered gravity conditions generated by two widely used platforms: parabolic flights and sounding rockets. These two platforms are of special interest because of the rather easy access compared to the extremely limited accessibilities of long-term microgravity experiments on satellites and the ISS. We present a microarray based analysis identifying stable reference genes in cells of the immune system exposed to short-term (several seconds) and middle-term (several minutes) altered gravity conditions on the two widely used platforms: parabolic flights and sounding rockets.

Our analyses of commonly used reference genes, ABC transporters and tRNA related genes, revealed that nine of the 17 genes suspected to be ubiquitously expressed are g-sensitive and therefore inappropriate for our purposes, amongst them being TATA box binding protein (TBP), a fundamental transcription factor for many genes, and seryltRNA synthetase (SARS), an essential enzyme for mRNA translation, also regulating vascular development (Table 7).

Two of the g-sensitive genes, that we identified in this study, are involved in multidrug resistance processes like the $\mathrm{ABC}$ transporters $\mathrm{ABCC} 4$ and transporter associated with antigen presenting 2 (TAP2). ABCC4 is of particular interest, because it has the ability to provide resistance to antiviral and anticancer nucleotide analogs and methotrexate $[72,73]$, acts as an independent regulator of intracellular cAMP, mediates cAMP dependent signal transduction to the nucleus, and controls human and rat smooth muscle cell (SMC) proliferation [74]. It is known that cAMP has largely inhibitory effects on components of macrophage activation and elevation of cAMP levels which suppresses FcgammaR-mediated phagocytosis [75]. Therefore, it would be interesting to look at this multidrug resistance-associated protein (ABCC4) in more detail in microgravity exposed cells to elucidate its role in the signaling cascades important for immune cell action and reaction under space conditions, as ABCC4 proved to be $\mu \mathrm{g}$-sensitive during parabolic and sounding rocket flight (Figures 8 and 9). Furthermore, TAP2 seems to be even more g-sensitive because it shows significant differential gene expression under $\mu$ g and hypergravity conditions during parabolic and sounding rocket flight (Figures 8 and 9). It will be interesting to further analyze the potential effects of differential gene expression of TAP2 because it is a key player in endogenous pathways for antigen presentation and involved in the cellular transport of antigens for subsequent association with MHC class I molecules [76]. An imbalance in its gene expression could lead to an impaired reactivity of cells of the immune system under altered gravity conditions.

Further standard genes as well as $\mathrm{ABC}$ transporters like RPLP0, ABCD4, and ABCF2 also turned out in our analysis to be g-sensitive. RPLP0 encodes for a ribosomal protein that is a component of the $60 \mathrm{~S}$ subunit and interacts with P1 and P2 to form pentameric complexes [77]. It is involved, for example, in Chagas disease [78] as well as mixed connective tissue disease [79]. The ABC transporters ABCD4 and $\mathrm{ABCF} 2$ are involved in transport of molecules across extra- and intracellular membranes like in peroxisomal import of fatty acids and/or fatty acyl-CoAs in the organelle [80] and play a role in suppression of volume-sensitive outwardly rectifying $\mathrm{Cl}$ channel (VSOR), respectively [81]. Altered expression levels of those genes by microgravity or hypergravity could have an impact on the translational level or the supply of the cell with essential resources important for proper cellular function. Recently it was shown that during parabolic flights the activity of the MRP2-ABC-transporter was significantly reduced [82]. Furthermore, under short duration spaceflight missions certain ABC transporter genes in the medically relevant species Salmonella sp. and Candida sp. were upregulated $[83,84]$.

Interestingly, we identified many of the g-sensitive genes not only reacting on $\mu \mathrm{g}$, but also on hypergravity indicating that not only the experimental g-conditions should be taken into account when selecting an appropriate reference gene, but also the accompanying g-conditions prevailing usually before $\mu \mathrm{g}$ is achieved. A detailed differential gene expression analysis of the parabolic flight and sounding rocket flight data sets for g-sensitive genes is currently ongoing.

Genes that proved to be stable over all g-conditions tested, were

(i) albumin (ALB), a protein comprising about one half of blood serum protein,

(ii) UDP-Gal:betaGlcNAc beta 1,4-galactosyltransferase, polypeptide 6 (B4GALT6), a type II membranebound glycoprotein important for glycolipid biosynthesis,

(iii) glyceraldehyde-3-phosphate dehydrogenase (GAPDH), a protein with several distinct functions, for example, the reversible oxidative phosphorylation of glyceraldehyde-3-phosphate,

(iv) hydroxymethylbilane synthase (HMBS), a protein catalyzing the head to tail condensation of four porphobilinogen molecules into the linear hydroxymethylbilane,

(v) tyrosine 3-monooxygenase/tryptophan 5-monooxygenase activation protein, zeta (YWHAZ), a gene product belonging to the 14-3-3 family of proteins that interacts with IRS1, suggesting a role in regulating insulin sensitivity,

(vi) ATP-binding cassette, subfamily A, member 5 (ABCA5), a membrane-associated protein belonging to the only major $\mathrm{ABC}$ subfamily found exclusively in multicellular eukaryotes with unknown function,

(vii) ATP-binding cassette, subfamily A, member 9 (ABCA9), another $\mathrm{ABC1}$ family member induced during monocyte differentiation into macrophages, and

(viii) ATP-binding cassette, subfamily C, member 1 (ABCC1), a member of the MRP subfamily of ABC transporters involved in multidrug resistance and 
functioning as a multispecific organic anion transporter.

Taken together, the compilation of genes that we present in Table 7 gives an overview about which genes are stably expressed during all investigated gravitational conditions lasting from seconds to minutes and can therefore be considered as suitable reference genes. Furthermore, Table 7 can be regarded as a tool for the community that can be easily adapted to select potential control genes in the design phase of a new, immune cell based, experiment on parabolic flights and sounding rocket flights because it provides valuable information about gene expression levels in $\mu \mathrm{g}$, as well as in $1.8 \mathrm{~g}$, in-flight $1 \mathrm{~g}$ and hardware ground control. Our results also allow for the identification of adaptation mechanisms by comparing short (parabolic flight) and intermediate (sounding rocket) microgravity periods and spot those genes that convert from sensitive into stable and vice versa. Our work should considerably facilitate identification of appropriate reference genes for individual experiments performed during parabolic flight and sounding rocket campaigns with immune cells, especially of the monocyte/macrophage system, in altered gravity.

$\begin{array}{ll}\text { Abbreviations } \\ \text { BL: } & \text { Baseline } \\ \text { CEV: } & \text { Centre d'essai en vol } \\ \text { CV: } & \text { Coefficient of variation } \\ \text { ESA: } & \text { European Space Agency } \\ \text { FBS: } & \text { Fetal bovine serum } \\ \text { FDR: } & \text { False discovery rate } \\ \text { DLR: } & \text { German Aerospace Center } \\ \text { H/W: } & \text { Hardware ground controls } \\ \text { HKG: } & \text { Housekeeping genes } \\ \text { hyper-g: } & \text { Hypergravity } \\ \text { IL: } & \text { Interleukin } \\ \text { ISS: } & \text { International Space Station } \\ \text { LPS: } & \text { Lipopolysaccharide } \\ \mu \text { g: } & \text { Microgravity } \\ \text { MMS: } & \text { Monocyte-macrophage system } \\ \text { PFC: } & \text { Parabolic flight campaign } \\ \text { qPCR: } & \text { Quantitative real-time PCR } \\ \text { RIN: } & \text { RNA integrity number } \\ \text { RPM: } & \text { Random positioning machine } \\ \text { ROS: } & \text { Reactive oxygen species } \\ \text { RWV: } & \text { Rotating wall vessel } \\ \text { SD: } & \text { Standard deviation } \\ \text { TNF- } \alpha: & \text { Tumor necrosis factor-alpha. } \\ & \end{array}$

\section{Conflict of Interests}

The authors declare that there is no conflict of interests regarding the publication of this paper.

\section{Authors' Contributions}

Oliver Ullrich and Cora S. Thiel developed the study idea, concept, and the overall study design in addition to planning, coordinating, and supervising the study. Cora S. Thiel, Liliana
E. Layer, and Swantje Hauschild wrote the paper. Oliver Ullrich edited the paper. Beatrice Lauber contributed to the paper. Liliana E. Layer, Cora S. Thiel, Oliver Ullrich, Svantje Tauber, Swantje Hauschild, Claudia Philpot, Annett Gutewort, Eva Hürlimann, Josefine Biskup, and Hartwin Lier performed the experiments during the 19th DLR parabolic flight campaign. Svantje Tauber, Cora S. Thiel, Felix Unverdorben, and Oliver Ullrich performed the experiments during the TEXUS-49 mission. Cora S. Thiel was responsible for sample analysis from the 19th DLR parabolic flight campaign and TEXUS-49 mission. Liliana E. Layer contributed to the sample analysis. Frank Engelmann contributed to and supervised the technical procedures during the 19th DLR parabolic flight campaign.

\section{Acknowledgments}

The authors gratefully acknowledge financial support by German Aerospace Center DLR (grants nos. 50WB0912 and 50WB1219). They also gratefully acknowledge the support of (in alphabetic order) Gesine Bradacs, Markus Braun, Miriam Christen, Giovanni Colacicco, Ulrike Friedrich, Nadine Gölz, André Hilliger, Andreas Huge, Schirin Ibrahim, Otfried Joop, Sonja Krammer, Andre Melik, Shirin Milani, Brice Mouttet, Marianne Ott, Irina Rau, Frank Rühli, Chen Sang, Burkhard Schmitz, Brita Scholte, Andreas Schütte, Johanna Stahn, Marc Studer, Susanne Wolf, and Fengyuan Zhuang.

\section{References}

[1] B. Comet, "Limiting factors for human health and performance: microgravity and reduced gravity. In: study on the survivability and adaptation of humans to long-duration interplanetary and planetary environments," Technical Note 2: Critical Assessments of the Limiting Factors for Human Health and Performance and Recommendation of Countermeasures HUMEXTN-002, 2001.

[2] G. Horneck, R. Facius, M. Reichert et al., "HUMEX, a study on the survivability and adaptation of humans to long-duration exploratory missions, part II: missions to Mars," Advances in Space Research, vol. 38, no. 4, pp. 752-759, 2006.

[3] G. Horneck and B. Comet, "General human health issues for Moon and Mars missions: results from the HUMEX study," Advances in Space Research, vol. 37, no. 1, pp. 100-108, 2006.

[4] N. Guéguinou, C. Huin-Schohn, M. Bascove et al., "Could spaceflight-associated immune system weakening preclude the expansion of human presence beyond Earth's orbit?" Journal of Leukocyte Biology, vol. 86, no. 5, pp. 1027-1038, 2009.

[5] H. Takayanagi, "Osteoimmunology: shared mechanisms and crosstalk between the immune and bone systems," Nature Reviews Immunology, vol. 7, no. 4, pp. 292-304, 2007.

[6] J. Caetano-Lopes, J. E. Canhão, and H. Fonseca, "Osteoimmunology - the hidden immune regulation of bone," Autoimmunity Reviews, vol. 8, no. 3, pp. 250-255, 2009.

[7] A. Cogoli, B. Bechler, O. Müller, and E. Hunzinger, "Effect of microgravity on lymphocyte activation," in Biorack on Spacelab D1, pp. 89-100, European Space Agency, Paris, France, 1988.

[8] A. Cogoli and A. Tschopp, "Lymphocyte reactivity during spaceflight," Immunology Today, vol. 6, no. 1, pp. 1-4, 1985. 
[9] A. Cogoli, A. Tschopp, and P. Fuchs-Bislin, "Cell sensitivity to gravity," Science, vol. 225, no. 4658, pp. 228-230, 1984.

[10] A. Cogoli, "Gravitational physiology of human immune cells: a review of in vivo, ex vivo and in vitro studies," Journal of Gravitational Physiology, vol. 3, no. 1, pp. 1-9, 1996.

[11] O. Ullrich, K. Huber, and K. Lang, "Signal transduction in cells of the immune system in microgravity," Cell Communication and Signaling, vol. 6, article 9, 2008.

[12] J. W. Armstrong, R. A. Gerren, and S. K. Chapes, "The effect of space and parabolic flight on macrophage hematopoiesis and function," Experimental Cell Research, vol. 216, no. 1, pp. 160168, 1995.

[13] M. Limouse, S. Manie, I. Konstantinova, B. Ferrua, and L. Schaffar, "Inhibition of phorbol ester-induced cell activation in microgravity," Experimental Cell Research, vol. 197, no. 1, pp. 8286, 1991.

[14] D. A. Schmitt, J. P. Hatton, C. Emond et al., "The distribution of protein kinase $\mathrm{C}$ in human leukocytes is altered in microgravity," FASEB Journal, vol. 10, no. 14, pp. 1627-1634, 1996.

[15] C.-L. Hsieh, P.-D. L. Chao, and S.-H. Fang, "Morin sulphates/ glucuronides enhance macrophage function in microgravity culture system," European Journal of Clinical Investigation, vol. 35, no. 9, pp. 591-596, 2005.

[16] I. Kaur, E. R. Simons, V. A. Castro, C. M. Ott, and D. L. Pierson, "Changes in monocyte functions of astronauts," Brain, Behavior, and Immunity, vol. 19, no. 6, pp. 547-554, 2005.

[17] A. Adrian, K. Schoppmann, J. Sromicki et al., "The oxidative burst reaction in mammalian cells depends on gravity," Cell Communication and Signaling, vol. 11, no. 1, article 98, 2013.

[18] M. A. Meloni, G. Galleri, P. Pippia, and M. Cogoli-Greuter, "Cytoskeleton changes and impaired motility of monocytes at modelled low gravity," Protoplasma, vol. 229, no. 2-4, pp. 243249, 2006.

[19] M. A. Meloni, G. Galleri, G. Pani, A. Saba, P. Pippia, and M. Cogoli-Greuter, "Space flight affects motility and cytoskeletal structures in human monocyte cell line J-111," Cytoskeleton, vol. 68, no. 2, pp. 125-137, 2011.

[20] M. Hughes-Fulford, T. Chang, and C.-F. Li, "Effect of gravity on monocyte differentiation," in Proceedings of the 10th ESA Life Sciences Symposium/29th Annual ISGP Meeting/24th Annual ASGSB Meeting/ELGRA Symposium "Life in Space for Life on Earth", pp. 22-27, 2008.

[21] C. Porcher, M.-C. Malinge, C. Picat, and B. Grandchamp, "A simplified method for determination of specific DNA or RNA copy number using quantitative PCR and an automatic DNA sequencer," BioTechniques, vol. 13, no. 1, pp. 106-114, 1992.

[22] R. Higuchi, C. Fockler, G. Dollinger, and R. Watson, "Kinetic PCR analysis: real-time monitoring of DNA amplification reactions," Nature Biotechnology, vol. 11, no. 9, pp. 1026-1030, 1993.

[23] P.-W. Chiang, W.-J. Song, K.-Y. Wu et al., "Use of a fluorescentPCR reaction to detect genomic sequence copy number and transcriptional abundance," Genome Research, vol. 6, no. 10, pp. 1013-1026, 1996.

[24] U. E. Gibson, C. A. Heid, and P. M. Williams, "A novel method for real time quantitative RT-PCR," Genome Research, vol. 6, no. 10, pp. 995-1001, 1996.

[25] C. A. Heid, J. Stevens, K. J. Livak, and P. M. Williams, "Real time quantitative PCR,” Genome Research, vol. 6, no. 10, pp. 986-994, 1996.
[26] H. D. VanGuilder, K. E. Vrana, and W. M. Freeman, "Twentyfive years of quantitative PCR for gene expression analysis," BioTechniques, vol. 44, no. 5, pp. 619-626, 2008.

[27] R. Biassoni and A. Raso, Eds., Quantitative Real-Time PCR: Methods and Protocols, Humana Press, New York, NY, USA, 2014.

[28] W. M. Freeman, D. J. Robertson, and K. E. Vrana, "Fundamentals of DNA hybridization arrays for gene expression analysis," BioTechniques, vol. 29, no. 5, pp. 1042-1055, 2000.

[29] S. Drăghici, Data Analysis for DNA Microarrays, Chapman \& Hall/CRC, Boca Raton, Fla, USA, 2003.

[30] H. C. Causton, J. Quackenbush, and A. Brazma, Microarray Gene Expression Data Analysis: A Beginner's Guide, Blackwell Publishing, Malden, Mass, USA, 2003.

[31] “The chipping forecast”" Nature Genetics, vol. 21, pp. 1-60, 1999.

[32] P. O. Brown and D. Botstein, "Exploring the new world of the genome with DNA microarrays," Nature Genetics, vol. 21, no. 1, pp. 33-37, 1999.

[33] D. J. Lockhart and E. A. Winzeler, "Genomics, gene expression and DNA arrays," Nature, vol. 405, no. 6788, pp. 827-836, 2000.

[34] A. Brazma, P. Hingamp, J. Quackenbush et al., "Minimum information about a microarray experiment (MIAME)-toward standards for microarray data," Nature Genetics, vol. 29, no. 4, pp. 365-371, 2001.

[35] R. D. Canales, Y. Luo, J. C. Willey et al., "Evaluation of DNA microarray results with quantitative gene expression platforms," Nature Biotechnology, vol. 24, no. 9, pp. 1115-1122, 2006.

[36] S. Lefever, J. Vandesompele, F. Speleman, and F. Pattyn, "RTPrimerDB: the portal for real-time PCR primers and probes," Nucleic Acids Research, vol. 37, no. 1, pp. D942-D945, 2009.

[37] F. Pattyn, P. Robbrecht, A. de Paepe, F. Speleman, and J. Vandesompele, "RTPrimerDB: the real-time PCR primer and probe database, major update 2006," Nucleic Acids Research, vol. 34, supplement 1, pp. D684-D688, 2006.

[38] X. Wang and B. Seed, "A PCR primer bank for quantitative gene expression analysis," Nucleic Acids Research, vol. 31, no. 24, article e154, 2003.

[39] S. A. Bustin, V. Benes, J. A. Garson et al., “The MIQE guidelines: minimum information for publication of quantitative real-time PCR experiments," Clinical Chemistry, vol. 55, no. 4, pp. 611-622, 2009.

[40] S. Taylor, M. Wakem, G. Dijkman, M. Alsarraj, and M. Nguyen, "A practical approach to RT-qPCR-Publishing data that conform to the MIQE guidelines," Methods, vol. 50, no. 4, pp. S1-S5, 2010.

[41] V. Marx, "PCR: living life amplified and standardized," Nature Methods, vol. 10, no. 5, pp. 391-395, 2013.

[42] S. A. Bustin, "Absolute quantification of mrna using real-time reverse transcription polymerase chain reaction assays," Journal of Molecular Endocrinology, vol. 25, no. 2, pp. 169-193, 2000.

[43] T. Suzuki, P. J. Higgins, and D. R. Crawford, "Control selection for RNA quantitation," BioTechniques, vol. 29, no. 2, pp. 332-337, 2000.

[44] O. Thellin, W. Zorzi, B. Lakaye et al., "Housekeeping genes as internal standards: use and limits," Journal of Biotechnology, vol. 75, no. 2-3, pp. 291-295, 1999.

[45] N. Tanic, M. Perovic, A. Mladenovic, S. Ruzdijic, and S. Kanazir, "Effects of aging, dietary restriction and glucocorticoid treatment on housekeeping gene expression in rat cortex and hippocampus-evaluation by real time RT-PCR," Journal of Molecular Neuroscience, vol. 32, no. 1, pp. 38-46, 2007. 
[46] T. D. Schmittgen and B. A. Zakrajsek, "Effect of experimental treatment on housekeeping gene expression: validation by real-time, quantitative RT-PCR," Journal of Biochemical and Biophysical Methods, vol. 46, no. 1-2, pp. 69-81, 2000.

[47] J. A. Warrington, A. Nair, M. Mahadevappa, and M. Tsyganskaya, "Comparison of human adult and fetal expression and identification of 535 housekeeping/maintenance genes," Physiol Genomics, vol. 2, no. 3, pp. 143-147, 2000.

[48] K. Dheda, J. F. Huggett, S. A. Bustin, M. A. Johnson, G. Rook, and A. Zumla, "Validation of housekeeping genes for normalizing RNA expression in real-time PCR," BioTechniques, vol. 37, no. 1, pp. 112-119, 2004.

[49] A. Radonić, S. Thulke, I. M. Mackay, O. Landt, W. Siegert, and A. Nitsche, "Guideline to reference gene selection for quantitative real-time PCR," Biochemical and Biophysical Research Communications, vol. 313, no. 4, pp. 856-862, 2004.

[50] M. W. Pfaffl, A. Tichopad, C. Prgomet, and T. P. Neuvians, "Determination of stable housekeeping genes, differentially regulated target genes and sample integrity: bestKeeper-excelbased tool using pair-wise correlations," Biotechnology Letters, vol. 26, no. 6, pp. 509-515, 2004.

[51] J. Vandesompele, K. De Preter, F. Pattyn et al., "Accurate normalization of real-time quantitative RT-PCR data by geometric averaging of multiple internal control genes," Genome Biology, vol. 3, no. 7, Article ID RESEARCH0034, 2002.

[52] J. H. Cai, S. Deng, S. W. Kumpf et al., "Validation of rat reference genes for improved quantitative gene expression analysis using low density arrays," BioTechniques, vol. 42, no. 4, pp. 503-512, 2007.

[53] R. A. Irizarry, B. Hobbs, F. Collin et al., "Exploration, normalization, and summaries of high density oligonucleotide array probe level data," Biostatistics, vol. 4, no. 2, pp. 249-264, 2003.

[54] Y. Benjamini and Y. Hochberg, "Controlling the false discovery rate: a practical and powerful approach to multiple testing," Journal of the Royal Statistical Society Series B: Methodological, vol. 57, no. 1, pp. 289-300, 1995.

[55] N. Silver, S. Best, J. Jiang, and S. L. Thein, "Selection of housekeeping genes for gene expression studies in human reticulocytes using real-time PCR," BMC Molecular Biology, vol. 7, article 33, 2006.

[56] J. Hellemans, G. Mortier, A. de Paepe, F. Speleman, and J. Vandesompele, "qBase relative quantification framework and software for management and automated analysis of real-time quantitative PCR data," Genome biology, vol. 8, no. 2, p. R19, 2007.

[57] J. Q. Clement, "Gene expression microarrays in microgravity research: toward the identification of major space genes," in Innovations in Biotechnology, E. C. Agbo, Ed., pp. 319-348, InTech, 2012.

[58] A.-I. Kittang, J. J. van Loon, O. Vorst, R. D. Hall, K. Fossum, and T.-H. Iversen, "Ground based studies of gene expression in Arabidopsis exposed to gravity stresses," Journal of Gravitational Physiology, vol. 11, no. 2, pp. P223-P224, 2004.

[59] M. Martzivanou, M. Babbick, M. Cogoli-Greuter, and R. Hampp, "Microgravity-related changes in gene expression after short-term exposure of Arabidopsis thaliana cell cultures," Protoplasma, vol. 229, no. 2-4, pp. 155-162, 2006.

[60] V. Chopra, A. A. Fadl, J. Sha, S. Chopra, C. L. Galindo, and A. K. Chopra, "Alterations in the virulence potential of enteric pathogens and bacterial-host cell interactions under simulated microgravity conditions," Journal of Toxicology and
Environmental Health Part A: Current Issues, vol. 69, no. 14, pp. 1345-1370, 2006.

[61] S. Yamada, T. Ganno, N. Ohara, and Y. Hayashi, "Chitosan monomer accelerates alkaline phosphatase activity on human osteoblastic cells under hypofunctional conditions," Journal of Biomedical Materials Research Part A, vol. 83, no. 2, pp. 290295, 2007.

[62] M. L. Lewis, L. A. Cubano, B. Zhao et al., "cDNA microarray reveals altered cytoskeletal gene expression in space-flown leukemic T lymphocytes (Jurkat)," The FASEB Journal, vol. 15, no. 10, pp. 1783-1785, 2001.

[63] M. A. Meloni, G. Galleri, S. Carta et al., "Preliminary study of gene expression levels in human T-cells exposed to cosmic radiations," Journal of Gravitational Physiology, vol. 9, no. 1, pp. P291-P292, 2002.

[64] S. J. Pardo, M. J. Patel, M. C. Sykes et al., "Simulated microgravity using the Random Positioning Machine inhibits differentiation and alters gene expression profiles of $2 \mathrm{~T} 3$ preosteoblasts," The American Journal of Physiology-Cell Physiology, vol. 288, no. 6, pp. C1211-C1221, 2005.

[65] J. W. Wilson, R. Ramamurthy, S. Porwollik et al., "Microarray analysis identifies Salmonella genes belonging to the low-shear modeled microgravity regulon," Proceedings of the National Academy of Sciences of the United States of America, vol. 99, no. 21, pp. 13807-13812, 2002.

[66] M. Wittwer, M. Flück, H. Hoppeler, S. Müller, D. Desplanches, and R. Billeter, "Prolonged unloading of rat soleus muscle causes distinct adaptations of the gene profile," The FASEB Journal, vol. 16, no. 8, pp. 884-886, 2002.

[67] Z. Q. Dai, R. Wang, S. K. Ling, Y. M. Wan, and Y. H. Li, “Simulated microgravity inhibits the proliferation and osteogenesis of rat bone marrow mesenchymal stem cells," Cell Proliferation, vol. 40, no. 5, pp. 671-684, 2007.

[68] K. M. Fridley, I. Fernandez, M.-T. A. Li, R. B. Kettlewell, and K. Roy, "Unique differentiation profile of mouse embryonic stem cells in rotary and stirred tank bioreactors," Tissue Engineering Part A, vol. 16, no. 11, pp. 3285-3298, 2010.

[69] A. Qian, S. Di, X. Gao et al., "cDNA microarray reveals the alterations of cytoskeleton-related genes in osteoblast under high magneto-gravitational environment," Acta Biochimica et Biophysica Sinica, vol. 41, no. 7, pp. 561-577, 2009.

[70] N. E. Ward, N. R. Pellis, S. A. Risin, and D. Risin, "Gene expression alterations in activated human T-cells induced by modeled microgravity," Journal of Cellular Biochemistry, vol. 99, no. 4, pp. 1187-1202, 2006.

[71] S. Zhao, W.-P. Fung-Leung, A. Bittner, K. Ngo, and X. Liu, "Comparison of RNA-Seq and microarray in transcriptome profiling of activated T cells," PLoS ONE, vol. 9, no. 1, Article ID e78644, 2014.

[72] Z.-S. Chen, K. Lee, and G. D. Kruh, "Transport of cyclic nucleotides and estradiol 17- $\beta$-D-glucuronide by multidrug resistance protein 4 . Resistance to 6-mercaptopurine and 6thioguanine," The Journal of Biological Chemistry, vol. 276, no. 36, pp. 33747-33754, 2001.

[73] Z.-S. Chen, K. Lee, S. Walther et al., "Analysis of methotrexate and folate transport by multidrug resistance protein 4 (ABCC4): MRP4 is a component of the methotrexate efflux system," Cancer Research, vol. 62, no. 11, pp. 3144-3150, 2002.

[74] Y. Sassi, L. Lipskaia, G. Vandecasteele et al., "Multidrug resistance-associated protein 4 regulates cAMP-dependent signaling pathways and controls human and rat SMC proliferation," 
The Journal of Clinical Investigation, vol. 118, no. 8, pp. 27472757, 2008.

[75] D. M. Aronoff, C. Canetti, C. H. Serezani, M. Luo, and M. Peters-Golden, "Cutting edge: macrophage inhibition by cyclic AMP (cAMP): differential roles of protein kinase A and exchange protein directly activated by cAMP-1," The The Journal of Immunology, vol. 174, no. 2, pp. 595-599, 2005.

[76] E. Procko and R. Gaudet, "Antigen processing and presentation: TAPping into ABC transporters," Current Opinion in Immunology, vol. 21, no. 1, pp. 84-91, 2009.

[77] K.-M. Lee, C. W. Yu, D. S. Chan et al., "Solution structure of the dimerization domain of ribosomal protein $\mathrm{P} 2$ provides insights for the structural organization of eukaryotic stalk," Nucleic Acids Research, vol. 38, no. 15, pp. 5206-5216, 2010.

[78] I. Ferrari, M. J. Levin, G. Wallukat et al., "Molecular mimicry between the immunodominant ribosomal protein P0 of Trypanosoma cruzi and a functional epitope on the human $\beta 1$ adrenergic receptor," Journal of Experimental Medicine, vol. 182, no. 1, pp. 59-65, 1995.

[79] R. W. Hoffman and M. E. Maldonado, "Immune pathogenesis of Mixed Connective Tissue Disease: a short analytical review," Clinical Immunology, vol. 128, no. 1, pp. 8-17, 2008.

[80] S. Kemp and R. J. A. Wanders, "X-linked adrenoleukodystrophy: very long-chain fatty acid metabolism, ABC halftransporters and the complicated route to treatment," Molecular Genetics and Metabolism, vol. 90, no. 3, pp. 268-276, 2007.

[81] Y. Ando-Akatsuka, T. Shimizu, T. Numata, and Y. Okada, "Involvements of the ABC protein ABCF2 and $\alpha$-actinin- 4 in regulation of cell volume and anion channels in human epithelial cells," Journal of Cellular Physiology, vol. 227, no. 10, pp. 3498-3510, 2012.

[82] S. Vaquer, E. Cuyàs, A. Rabadán, A. González, F. Fenollosa, and R. de la Torre, "Active transmembrane drug transport in microgravity: a validation study using an ABC transporter model," F1000Research, vol. 3, article 201, 2014.

[83] J. W. Wilson, C. M. Ott, K. Höner Zu Bentrup et al., "Space flight alters bacterial gene expression and virulence and reveals a role for global regulator Hfq," Proceedings of the National Academy of Sciences of the United States of America, vol. 104, no. 41, pp. 16299-16304, 2007.

[84] A. Crabbé, S. M. Nielsen-Preiss, C. M. Woolley et al., "Spaceflight enhances cell aggregation and random budding in Candida albicans," PLoS ONE, vol. 8, no. 12, Article ID e80677, 2013.

[85] C. K. Mantri, J. P. Dash, J. V. Mantri, and C. C. V. Dash, "Cocaine Enhances HIV-1 Replication in CD4+ T Cells by Down-Regulating MiR-125b," PLoS ONE, vol. 7, no. 12, Article ID e51387, 2012.

[86] F. Jacob, R. Guertler, S. Naim et al., "Careful selection of reference genes is required for reliable performance of RTqPCR in human normal and cancer cell lines," PLoS ONE, vol. 8, no. 3, Article ID e59180, 2013.

[87] A. Marcant, A. Denys, A. Melchior et al., "Cyclophilin B attenuates the expression of TNF- $\alpha$ in lipopolysaccharide-stimulated macrophages through the induction of B cell lymphoma-3," The Journal of Immunology, vol. 189, no. 4, pp. 2023-2032, 2012.

[88] B. P. Barna, I. Huizar, A. Malur et al., "Carbon nanotubeinduced pulmonary granulomatous disease: twistl and alveolar macrophage M1 activation," International Journal of Molecular Sciences, vol. 14, no. 12, pp. 23858-23871, 2013.

[89] J. P. Chou, C. M. Ramirez, J. E. Wu, and R. B. Effros, "Accelerated aging in HIV/AIDS: novel Biomarkers of Senescent Human CD8+ T Cells," PLoS ONE, vol. 8, no. 5, Article ID e64702, 2013. 

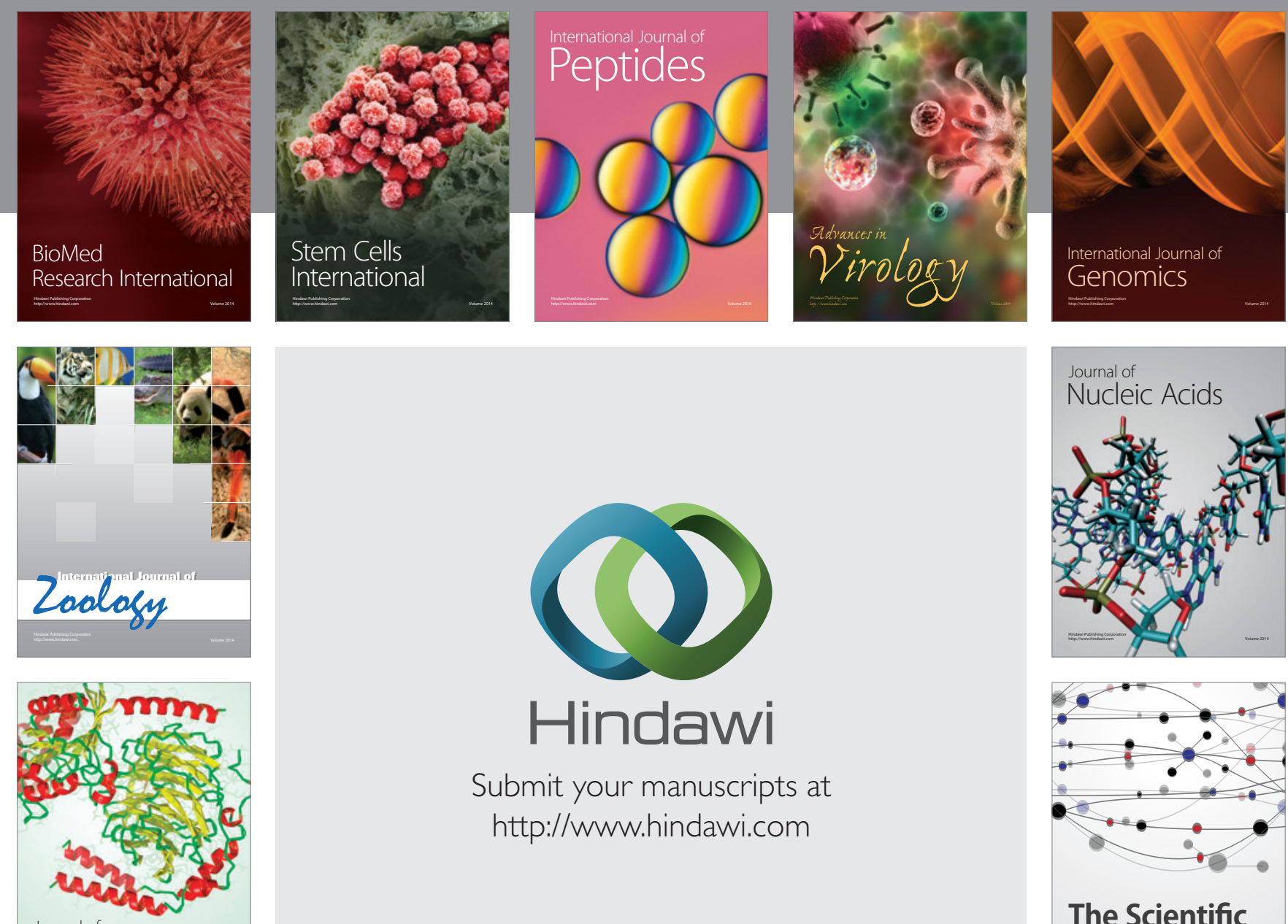

Submit your manuscripts at

http://www.hindawi.com

Journal of
Signal Transduction
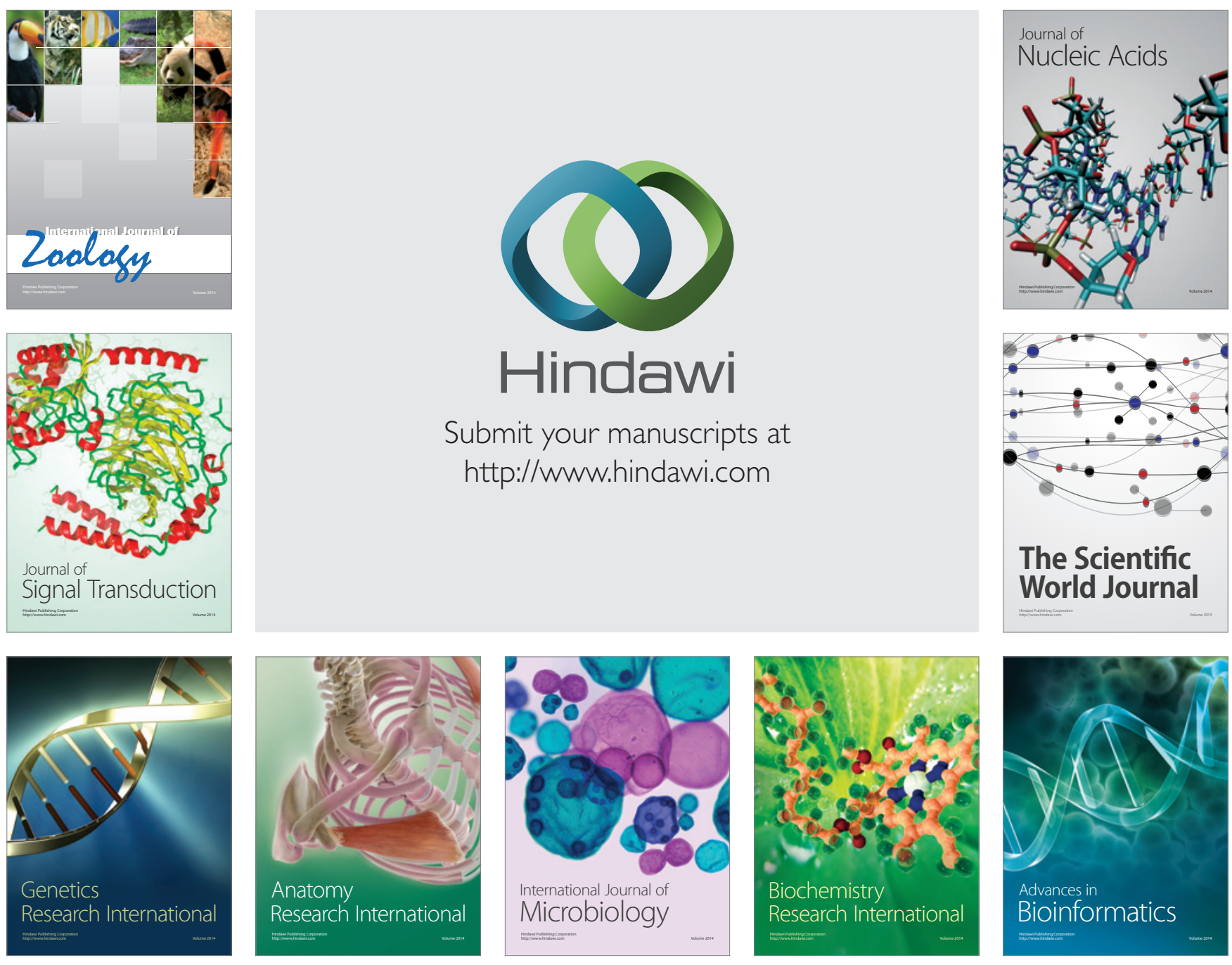

The Scientific World Journal
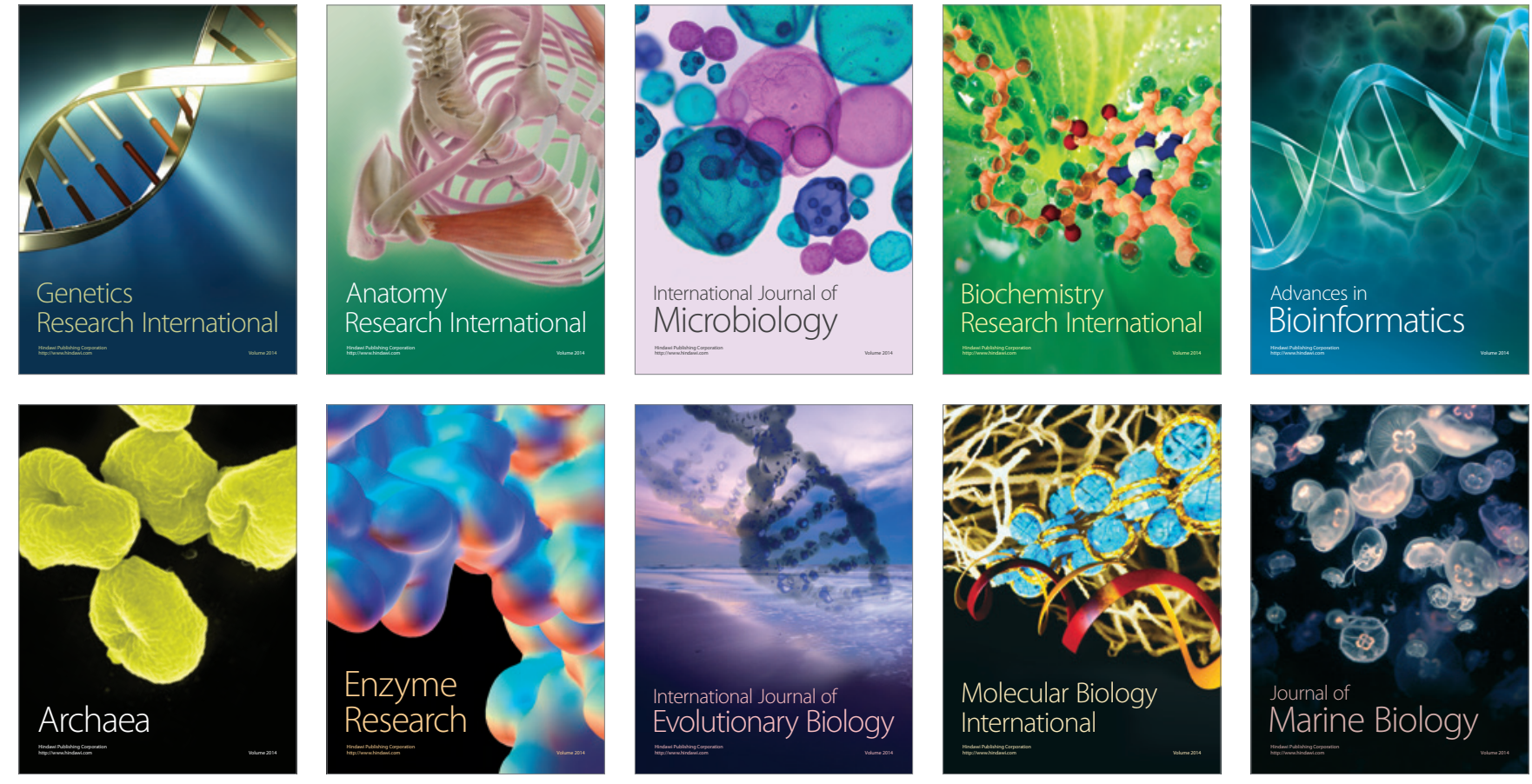